\title{
Areniscas ornamentales empleadas en Ciudad Rodrigo, Salamanca: caracterización petrográfica y química de los materiales de cantera
}

\author{
Ornamental sandstones used in Ciudad Rodrigo, \\ Salamanca: petrographic and chemical characterization \\ of the quarry materials
}

\begin{abstract}
VARAS, M. J. ${ }^{(1 " 1)} ;$ MOLIN $\Lambda$, E. ${ }^{\left(2^{*}\right)}$; VICENTE. M. A. ${ }^{\left(1^{* 1}\right)}(+)$
(1) Instituto de Recursos Naturales y Agrobiología (IRNA-CSIC) (en la actualidad: Inst.Geografía Económica) (2) Departamento de Geología, Universidad de Salamanca (") Unidad Asociada CSIC. Univ. Salamanca

Fecha de recepción: 19-IX-01
\end{abstract}

Fecha de aceptación: 16-XI-0I

ESPAÑA

\begin{abstract}
RESUMEN
El estudio petrográfico y químico de las llamadas

"Areniscas de Ciudad Rodrigo" permite definir una serie de variedades pétreas (Roja, Marrón, Rayada, Nodular y Blanca) que, en mayor o menor medida, han sido utilizadas en la construcción del casco histórico de esta ciudad. Su proximidad a la ciudad hizo que ta extracción se viera favorecida desde tiempos remotos.
\end{abstract}

Presentan variaciones químicas y mineralógicas importantes como consecuencia de los múltiples procesos diagenéticos acontecidos a lo largo de toda su historia geológica. Estas modificaciones se traducen en diversas variedades pétreas cuya gran vistosidad queda reflejada en la sillería de los edificios históricos, haciendo de Ciudad Rodrigo un Conjunto Arquitectónico muy pintoresco.

\section{SUMMARY}

Petrographic and chemical study of the Ciudad Rodrigo (province of Salamanca, Spain) sandstones reveals the existence of several types of stone (Red, Brown, Striped, Nodular and White). To some extent all of them have been used in the construction of the historical part of this city. The proximity of the quarries to the city has meant that they have been used for such purposes since remote times.

The types of stone display important chemical and mineralogical variations as a result of the many diagenetic processes they have been subjected to over time. These alterations are reflected in the different varieties, whose splendour can be fully appreciated in the masonry of the historical buildings comprising the architectural ensemble of the city.
PALABRAS ClAVE: areniscas, diagénesis, canteras, edificación, Ciudad Rodrigo

\section{INTRODUCCIÓN}

La arenisca es la piedra por excelencia utilizada por las gentes de Ciudad Rodrigo, para la construcción de toda su riqueza monumental (Fig.1). Desde el punto de vista geológico, este tipo de material rellena el extremo occidental de la "Fosa de Ciudad Rodrigo", una pequeña cuenca tectónica de carácter continental y edad
KEYWORDS: dundstones, diagenesis, quarries, building, Ciudad Rodrigo

\section{INTRODUCTION}

Sandstone is the type of stone par excellence used by builders in Ciudad Rodrigo to create the monumental part of the city (Fig. I). From the geological point of view, this type of material fills western end of the

"Ciudad Rodrigo Fossa", a small tectonic basin of 
terciaria (Fig. 2). Son unas areniscas subarcósicas ricas en cloritas férricas, micas dioctaédricas, cuarzos y feldespatos, que proceden de la erosión de elevaciones montañosas de naturaleza metamórfica, localizadas en su borde SE ("Sicrra de Francia") (3). Las "Areniscas de Ciudad Rodrigo" s.l. han sido estudiadas y datadas como Eoceno por numerosos autores $(4,5,6,7)$, que las han designado de diversas formas ("Areniscas Arcósicas Inferiores", "Serie de Ciudad Rodrigo", "Serie Arcósica Inferior", "Ciclo Subarcósico", etc.) pero con las mismas características litológicas y localización estratigráfica en la zona.

Las zonas de extracción se localizan en las proximidades de la ciudad. El principal afloramiento ("Las Canteras") forma parte de un escarpe creado por la crosión del río Águeda en su margen derecha y sobre el que asienta todo el recinto amurallado de Ciudad Rodrigo (Figs. 2 y 3). Este afloramiento está constituido por facies sedimentarias (fangos-arenosos, areniscas y conglomerados) de granulometría creciente hacia su parte alta (Fig. 3). Los diez últimos metros de este afloramiento han sido y son muy apreciados para la construcción. debido a su dureza y alta vistosidad. continental character and Tertiary age (Fig. 2). The sandstones are subarkose and rich in ferric chlorites. dioctahedral micas, quarties and feldspars, among other components, and have arisen from the erosion of mountains comprising metamorphic materials located at their SE rim ("Francia Sierra") (3). The "Ciudad Rodrigo Sandstones" s.l. have been studied and dated as Eocene by several authors $(4,5,6,7)$. These authors have designated them as having varied forms " Arkose Lower Sandstones".

"Ciudad Rodrigo Series", "Lower Arkose Series", "Subarkos Cycle", etc.), although coinciding in their lithologic characteristics and stratigraphic location in the sone.

The rones where these stones are quarried are close to the city. The main outcrop ("Las Canteras") forms part of an escarpment that has been created by erosion of the Águeda River on its bank right. Over this escarpment is located the walled part of the city (Figs. 2 and 3). The outcrop is made up of sedimentary facies (sandy muds, sandstones and conglomerates) whose grain size increases upward (Fig. 3). The last ten metres of this outcrop have and continue to be much appreciated for construction owing to the hardness of the stone obtained

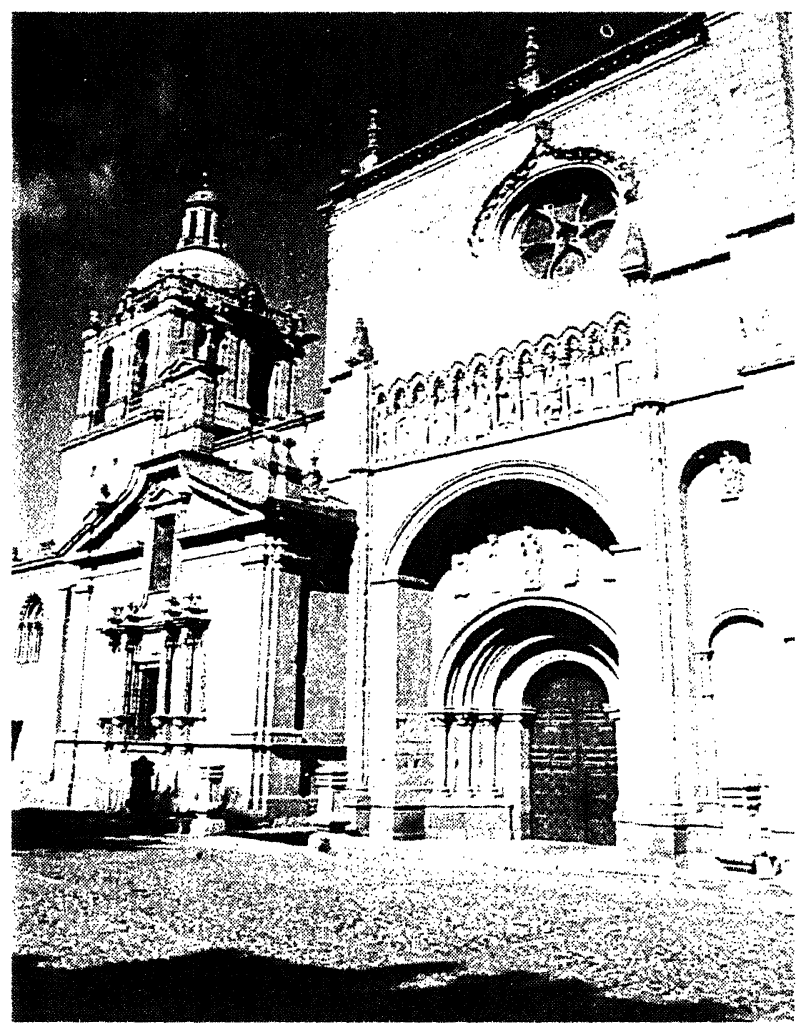

I:igura 1.- Catedral de Sta Maria. Monumento representativo del Patrimonio Aryuitectónico de (iudad Rodrigo

Figure 1.. Sta. Maria Cathedral. This is a representative monument of the Arehiterefural Heritage of ("iudad Rodriger 


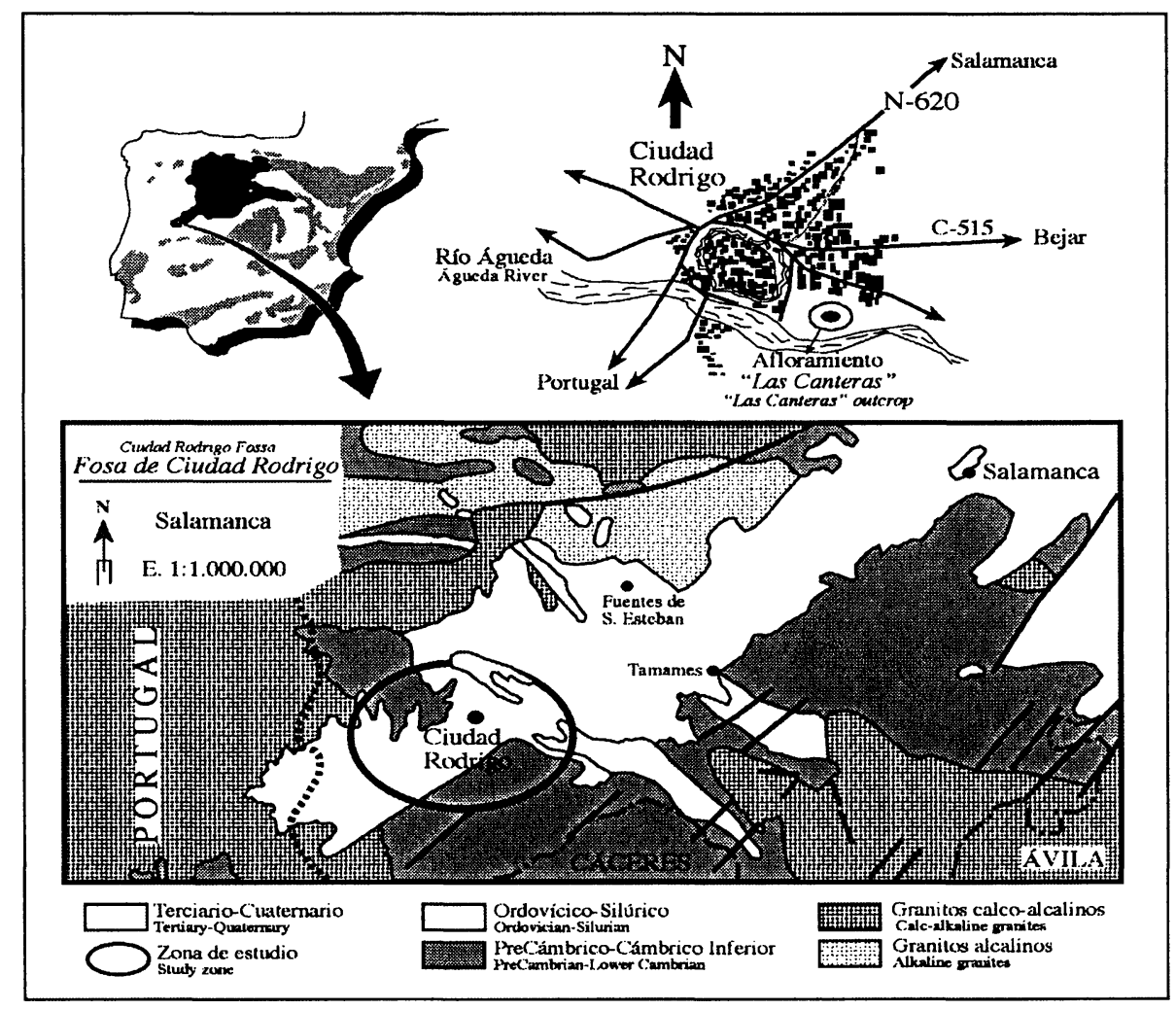

Figura 2.- Localización geográfica y mapa geológico de la zona de estudio $(1,2)$.

Figure 2.- Location geography and geological map of the study zone $(1,2)$.

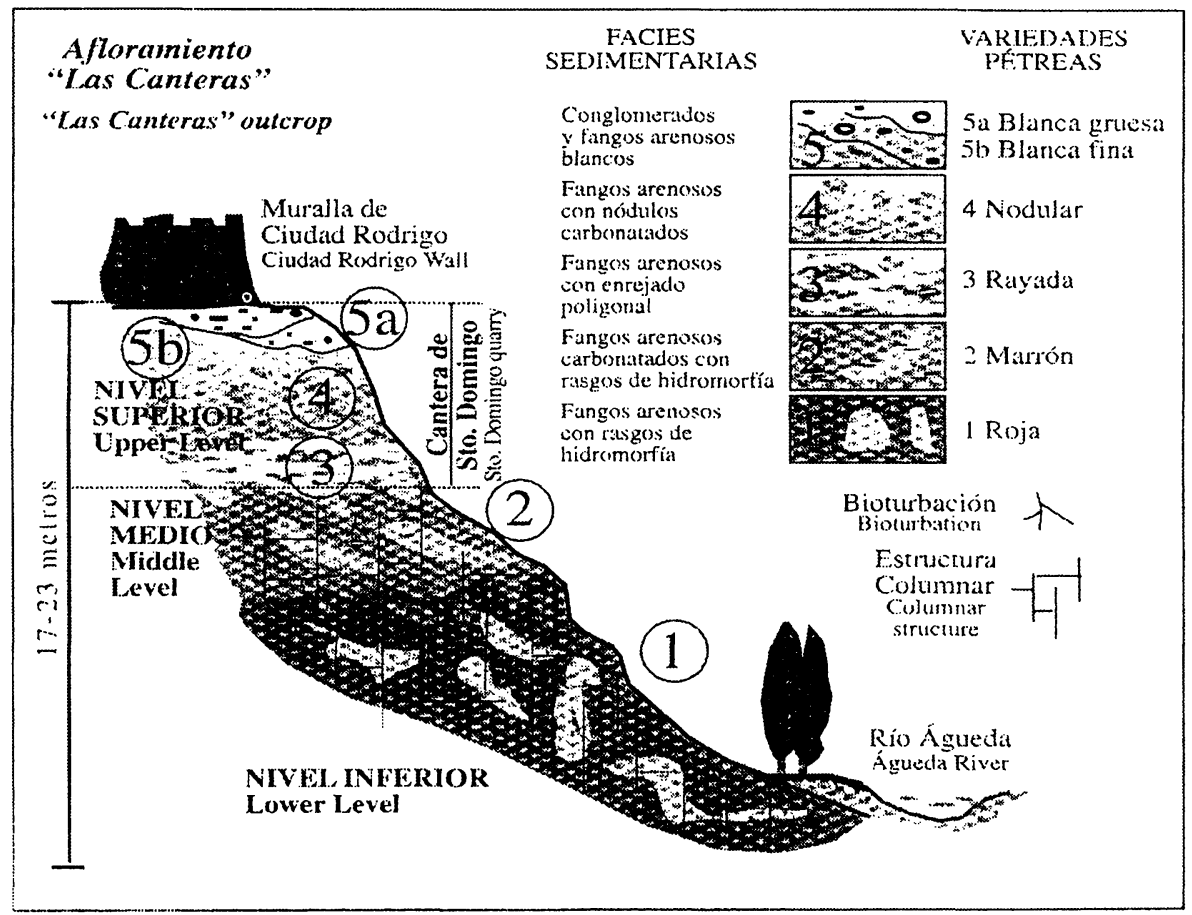

Figura 3.- Esquema del afloramiento "Las Canteras" y localización dentro del mismo de la "Cantera de Santo Domingo", así como de las cinco variedades pétreas identificadas.

Figure 3.- Location of the "Santo Domingo Quarry" in the "Las Canteras" outcrop and the five varieties of stone identified: 1-Red, 2-Brown, 3Striped, 4-Nodular, 5a-Coarse White and 5b-Fine White. The sedimentary facies with which these varieties of stone are identified are: 1-Sandy muds with hydromorphic features; 2-Carbonated sandy muds with hydromorphic features; 3-Sandy muds with a polygonal lattice: 4-Sandy muds with carbonated nodules, and $5 a / 5 b$-White conglomerates and sandy muds. 
Por el contrario, las partes bajas, aunque se han detectado en algunos muros de edificios, se han empleado más en la industria de la cerámica, pero sin mucho éxito.

Antiguos libros y actas municipales documentan la existencia de numerosas canteras utilizadas desde el siglo XII y localizadas en la parte alta de este frente de escarpe. Las más importantes son las de "San Juan" y "Sto. Domingo". La primera cantera, como tal, no existe actualmente al haber sido cubierta por edificaciones más recientes. Estaba catalogada como una cantera de picdra de buena calidad y era utilizada, casi exclusivamente, para portadas, ventanas y esquinas. Se sabe que eran facies finas de color blanco y alta compactación, fáciles de trabajar y labrar. La cantera de "Sto. Domingo", actualmente en uso, aparece lateralmente a la anterior y presenta, por lo general, mayor granulometría (conglomerados). La piedra de esta cantera era utilizada para la construcción de los muros de los edificios, lo que denota su mala calidad (8).

El afloramiento de "Las Canteras" se corresponde con un importante perfil de transformación originado por los múltiples procesos diagenéticos que afectaron a la arenisca original una vez depositada. De base a techo, se pueden distinguir tres niveles diagenéticos distintos, identificándose en cada uno de ellos una serie variedades pétreas de naturaleza diversa y origen común (Fig. 3). Las transformaciones que se observan están condicionadas por la dinámica y la evolución en el tiempo de las aguas meteóricas, tanto en condiciones freáticas como vadosas (9). Estos niveles son:

- Nivel Inferior. Arenisca subarcósica original cuya matriz está formada por arcillas heredadas (illitas/ moscovitas y cloritas). Los procesos diagenéticos son escasos pero existe hidrólisis y argilización. La variedad pétrea identificada la vamos a denominar ROJA (Fig. 4a).

- Nivel Medio. Arenisca donde la matriz ha sido parcial o totalmente reemplazada por un plasma carbonatado de dolomita. La carbonatación es el proceso diagenético más importante. En la parte baja de este nivel se ha identificado la variedad MARRÓN (Fig. 4b) y en su parte alta, la variedad RAYADA (Fig. 4c).

- Nivel Superior. Arenisca y/o conglomerado donde aparece un plasma de naturaleza arcillosa (palygorskita). Este tipo de plasma coexiste en mayor o menor grado con el carbonatado. Este nivel es el there, and its colourfulness. By contrast, even though they have been used in the walls of some buildings the lower parts have mainly been used in the ceramic industry, although with little success.

Old books and municipal records document the existence of many quarries in use since the twelfth century; these are located on the upper part of the scarp front. The most important are the "San Juan" and "Santo Domingo" quarries. The former ("San Juan Quarry") no longer exists as an actual quarry since it has been built on. It was catalogued as a quarry containing high quality stone and was used almost exclusively for portals, windows and corners. The facies are known to have been fine-grained. white, highly compact and easy to work and dress. The "Santo Domingo" quarry, -still in use-is located laterally to that of "San Juan" and in general is of larger grain sise (conglomerates). The stone from this quarry has traditionally been used for the construction only of the walls of buildings, indicating its poor quality (8).

\section{The "Las Canteras" outcrop is an important} transformation profile originated by the many diagenetic processes undergone by the original sandstone once deposited. From bottom to top it is possible to distinguish three different diagenetic levels, each containing a series of different varieties of stone, although all are of a common origin (Fig. 3). The observed alterations have been governed by the dynamics and evolution over time of meteoric water, both in phreatic and vadose conditions (9). These levels are as follows:

- The Lower Level. This is original subarkose sandstone whose matrix is made up of inherited clays (illites/muscovites and chlorites). Diagenetic processes are few although hydrolysis and argillization can be appreciated. Here, the variety of stone identified is referred to as RED (Fig. 4a).

The Middle Level. This comprises sandstone whose matrix has been partially or wholly replaced by dolomitic plasma. Carbonation is the most important diagenetic process observed. The lower part of this level contains the stone referred to here as BROWN (Fig. 4b) and the upper part displays the STRIPED) rariety (Fig. 4c).

\footnotetext{
- The Upper level. This is a sandstone and/or conglomerate, containing clavey plasma (palygorskite). To a greater to lesserer extent, this type of plasma coevists with the carbonated type. This level exhibits
} 
que presenta mayor transformación diagenética, siendo la argilización a palygorskita el proceso más importante. Aquí se identifican la variedad NODULAR (Fig. 4d), en su base, y la variedad BLANCA (Figs. 4e y 4f), en su techo. Esta última the greatest degree of diagenetic transformation. the most important process being argilliation to palygorskite. The level contains the NODULAR variety of stone (Fig. 4d) at the base and the WHITE variety (Figs. 4e and 4f) at the top. The latter has two different grain types (sandstone and

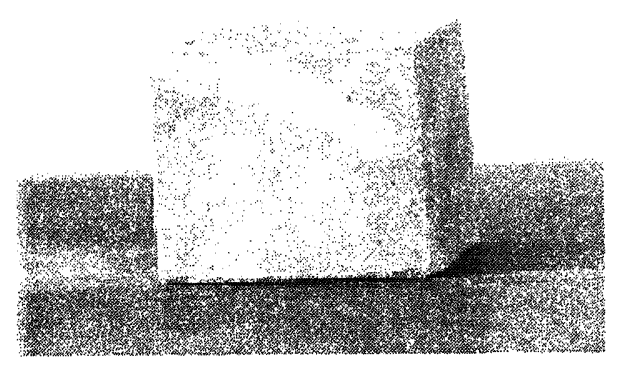

a)

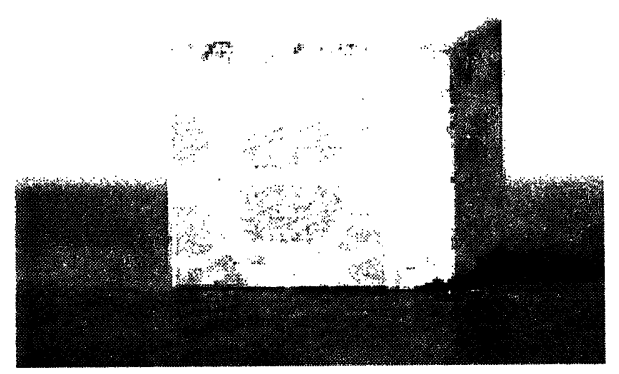

c)

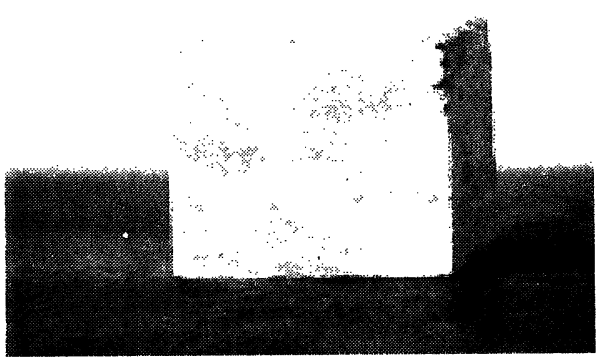

e)

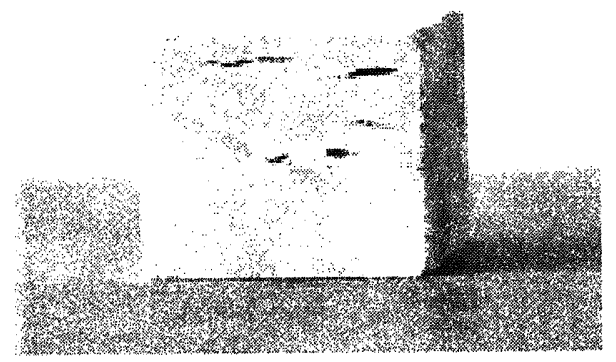

b)

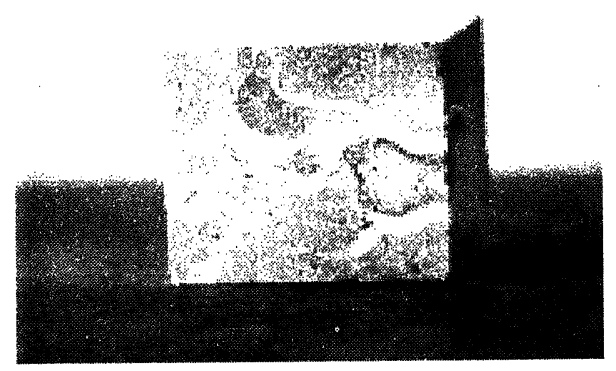

d)

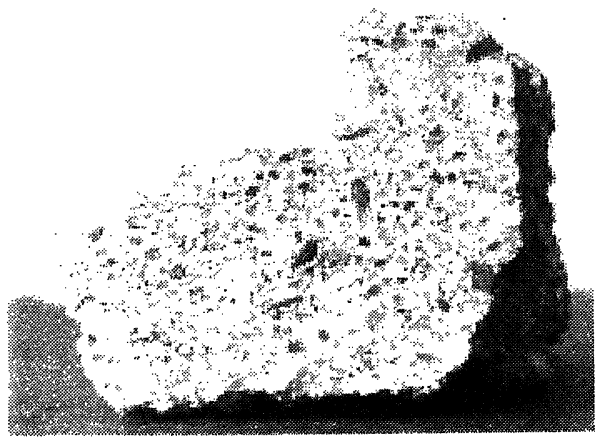

f)

Figura 4.- Aspecto de las diferentes variedades pétreas identificadas: a) Variedad Roja: b) Variedad Marrón: c) Variedad Rayada, d) Variedad Nodular, e) facies Fïna y f) Gruesa de la Variedad Blanca.

Figure 4.- Aspect of the different varieties of stone identificel: a) Red Variety; b) Brown Varicty: (') Striped Variety: al) Nodular Variety, e) Fine facies and f) ('oarse facie's of the White Variets: 
Variedad pétrea se presenta en dos granulometrías distintas (areniscas y conglomerados) que las hacen diferir en sus propiedades petroquímica.

El estudio de estos procesos diagenéticos nos obliga a precisar algunos términos que se utilizan en este trabajo. siguiendo la bibliografía más reciente sobre petrología y alteraciones $(10,11,12.13)$ :

- Matriz. Material fino $(<2 \mu \mathrm{m})$ de un sedimento que aparece entre los granos gruesos (esqueleto). Está compuesto por minerales primarios de origen alóctono y no transformados durante los procesos postsedimentarios (procesos diagenéticos o de alteración).

- Cemento. En la términología petrográfica implica: a) que se trata de un material de precipitación química a partir de soluciones, b) que tiene una procedencia alóctona y c) que rellena una cavidad previa existente.

- Plasma. Este término procede de los estudios sobre suelos y alteración por meteorización de rocas. Se utiliza para designar al material fino originado en las alteraciones y/o recmplazamientos, independientemente de si el material original afectado fuera la matriz o los granos del esqueleto. Existen dos tipos principales de plasma, que pueden ser a) de naturaleza arcillosa ("argiliplasma") y b) de naturaleza más o menos cristalina ("cristaliplasma"). Ambos implican transformaciones in situ de los minerales primarios por procesos tanto aditivos como sustractivos.

Pensamos que para el estudio de los procesos diagenéticos en sedimentos de cuencas continentales donde las aguas meteóricas ha jugado un papel fundamental, los criterios y métodos para el estudio de las alteraciones y los paleosuelos son los más adecuados. Por ello, utilizamos el término "plasma". en lugar de "cemento".

Las canteras de "San Juan" y "Sto. Domingo" comprenden el nivel Superior y la parte alta del nivel Medio; lo que coincide con la extracción de las variedades Rayada, Nodular y Blanca (9) (Fïg. 3). Los tres tipos de arenisca se identifican perfectamente, a simple vista, en todos los monumentos de Ciudad Rodrigo.

Por consiguiente, con este trabajo se pretende profundizar en el conocimiento de la naturaleza química y mineralógica de las principales variedades pétreas utilizadas en la construcción de los edificios de esta ciudad. Este conocimiento previo de los materiales con los que se va a trabajar, facilitará la manera de intervenir en su rehabilitación sin distorsionar el aspecto original de paramentos, ventanas. cornisas. bóvedas. portadas. etc. conglomerates), and hence their petrochemical properties are different.

Study of these diagenetic processes makes it necessary to define the terminology appearing here, following that used in the current literature $(10,11,12,13)$ :

Matrix. Is the fine material $(<2 \mu \mathrm{m})$ of a sedimentary rock appearing amongt the coarse (skeleton) grains. It is allochthonous in origin and is formed by minerals not transformed by the post-sedimentary (diagenetic: weathering) processes.

- Cement. Is a petrographic term, implying: a) a (hemical nature (mainly precipitation from a solution), b) an allochthonous source, and ()) the filling of previous roids.

- Plasma. This term comes from the Soils and Weather sciences and refers to the fine material developed by weathering andlor replacement regardless of whether if the affected original material is the matrix or the skeletal grains. Tivo types of plasma are distinguished: a) clayey (argilliplasma) and b) more or less crystalline (crystalliplasma), although both types are generated in situ by additive and/or subtractive processes.

Study of the first steps of diagenesis undergone by sediments filling small and shallow continental basins in which meteoric water has had an important role, which is our case, must be carried out based on the ariteria and methodology used for palaeosoils and palaeoweathering. Therefore, we use the term "plasma" in this work instead of "cement"

The "San Juan" and "Santo Domingo" quarries comprise the Upper Level and the upper part of the Middle Le'vel, which coincide with the extraction of the Striped. Nodular and White varieties (9) (Fig. 3). These three types of sandstone are perfectly visible in all the buildings of Ciudad Rodrigo.

With the foregoing as background, the aim of the present work was to gain further insight into the chemical and mineralogical nature of the main raricties of stone used in the buildings of the city: Knowledge of the materials to be used in construction should help in the maintenance and upke'p of such buildings, without distorting the original aspect of their walls, windows, cornices, ceiling vaults, portals, etc. 


\section{METODOLOGÍA}

En los tres niveles diagenéticos identificados en el afloramiento de "Las Canteras", se recogieron muestras representativas de las facies sedimentarias que definen los cinco tipos de variedades pétreas.

El estudio mineralógico y micromorfológico comenzó con la observación minuciosa de los materiales en el campo y prosiguió en el laboratorio con el empleo del microscopio petrográfico LEITZ LABORLUUX-12 POL $S$, teniendo en cuenta criterios de Boulet et al. (14), Thiry (15), Bullock et al. (16) y Nahon (11). El empleo de la microscopía óptica se vio corroborado por la utilización de otras técnicas, tales como la difracción de rayos $X(D R X)$ y los análisis térmicos (DTA-TG). Con la DRX se obtuvieron diversos diagramas de difracción tanto de polvo cristalino de muestra total como de agregado orientado de la fracción arcilla $(<2 \mu \mathrm{m})$. Para ello se utilizó un equipo, modelo PHILIPS PW-1730, con goniómetro PW-1050/81. El análisis cualitativo de las especies minerales existentes en las respectivas muestras se llevó a cabo siguiendo las indicaciones del fichero JCPDS del "International Centre for Diffraction Data" (17) y de autores tales como Brindley y Brown (18), Lindholm (19) y Hardy y Tucker (20). Del mismo modo, la semicuantificación se basó en el método de Schultz (21) salvo pequeñas modificaciones de Davies y Hooper (22), Runnells (23) y Barahona (24).

Para la realización de los análisis térmicos (DTA-TG) se empleó un equipo PERKIN-ELMER, compuesto de un aparato de análisis térmico-diferencial (DTA 1700) y una termobalanza (TGS-2). La interpretación de los resultados, se apoyó en la información aportada por los tratados de Mackenzie (25) y Paterson y Swaffield (26).

Finalmente, y para profundizar y/o puntualizar en aquellos detalles poco claros se hizo uso del microscopio electrónico de barrido (SEM). Los equipos empleados fueron un ZEISS DSM-940 y un ZEISS DSM-960, ambos con microanálisis de energía dispersa de rayos $\mathrm{X}$ (EDS).

El color es una de las características elementales a tener en cuenta en un material de construcción. La medición del color se realizó mediante un colorímetro para sólidos de MINOLTA CR-300 y se contrastó con las cartas de colores de Munsell (27). El sistema de color recomendado por la $\mathrm{CIE}(28)(\mathrm{L}, \mathrm{a}, \mathrm{b})$ representa con fidelidad la sensibilidad humana del color. L es la variable luminosa y a y b son las coordenadas de cromaticidad.

Las propicdades hídricas de estas piedras se determinaron siguiendo las recomendaciones de las normas de la RILEM $(29,30)$, NORMAL, $(31,32)$ y la Norma Francesa (33).

\section{METHODOLOGY}

Representative samples of the sedimentary facies defining the five varieties of stones were collected from all three diagenetic levels identified at the "Las Canteras" outcrop.

The mineralogical and micromorphological study began with a meticulous observation of the materials in the field and then at the laboratory, using a LEITZ LABORLUX-12 POL S petrographic microscope, following the criteria of Boulet et al. (14), Thiry (15), Bullock et al. (16) and Nahon (11). The petrographic microscope findings were corroborated by the use of other techniques, such as $X$-ray diffraction (XRD) and thermal analyses (DTA-TG). XRD afforded different diffraction diagrams both of the crystalline powdered fraction of total samples andlor oriented aggregates of the clay fraction $(<2 \mu \mathrm{m})$. To obtain them, a PHILIPS PW-1730 apparatus was used, with a PW-1050/81 goniometer: Qualitative analysis of the mineral species present in the respective samples was carried out following the indications of the JCPDS file of the International Centre from Diffraction Data (17) and of authors such as Brindley and Brown (18), Lindholm (19) and Hardy and Tucker (20). Semiquantification was based on the method of Schult: (21), using the modifications of Davies and Hooper (22), Runnells (23) and Barahona (24).

In the thermal analyses (DTA-TG), a PERKIN-ELMER apparatus was used, comprising a differential thermal analysis device (DTA 1700) and a thermobalance (TGS-2). Interpretation of the results was based on the work of Mackenzie (25), Patterson and Swaffield (26).

Finally, to clarify any obscure points, a scanning electron microscope (SEM) was used. The devices used were a ZEISS DSM-940 and a ZEISS DSM-960, both with $X$-ray dispersive energy microanalysis (EDA).

Colour is one of the elemental characteristics to be considered in a construction material. The colour measurement were made using a colormeter for solids. model MINOLTA CR-300. For this measurement, Munsell Colour Charts (27) were used. The colour system recommended by the CIE (28) ( $L, a, b)$ faithfully represents also human sensitivity to colour. $L$ is the luminosity variable, and a and b are the chromatic coordinates.

The hydric properties of these stones were determined according to the recommendations of the norms of the RILEM (29, 30), the NORMAL (31,32) and the French Norm (3.3). 
Por último, la caracterización química de las cinco variedades pétreas identificadas, consistió en la determinación de sus elementos mayores. Para ello, se realizó un ataque en medio ácido $\left(\mathrm{NO}_{3} \mathrm{H}+\mathrm{FH}\right)$ bajo presión en un digestor de microondas (MILESTONE MLS-1200) y las disoluciones obtenidas fueron tamponadas con ácido bórico. La identificación de los clementos se realizó por emisión en Plasma ICP, modelo Plasma II de PERKIN-ELMER.

\section{RESULTADOS Y DISCUSIÓN}

Los resultados que a continuación se exponen reflejan la existencia de una clara separación entre las cinco variedades de arenisca propuestas (Roja, Marrón, Rayada, Nodular y Blanca). En el afloramiento de "Las Canteras", estas variedades pétreas forman parte de facies sedimentarias transformadas por los procesos diagenéticos. Son facies que se interdigitan entre sí, tanto lateral como verticalmente. Esto significa que las variedades pétreas, aunque sc encuentran en un espacio definido dentro del afloramiento, no cuentan con bordes claros que las separen, por lo que su extracción se limita a la longitud y espesor que tenga la facies sedimentaria en cuestión (Fig. 3).

\section{Características macroscópicas y microscópicas}

La variedad Roja aparece en la zona basal, coincidiendo con el nivel Inferior del afloramiento de "Las Canteras" y con los materiales arenosos originales (Figs. 3 y 4a). Se trata de un fango arenoso y masivo que presenta fuertes contrastes de color (rojos y verdes), originados por procesos de hidromorfía (Tabla 1). Es un material deleznable (Tabla 2) por lo que las gentes del lugar la han empleado más que para la construcción, para la industria de la cerámica. Su estudio al microscopio petrográfico y electrónico de barrido, revela que es un material silíceo constituido por un esqueleto de origen metamórfico (cuarzo mono- y policristalino, feldespatos, fragmentos de cloritoesquistos y micaesquistos, illitas/moscovitas, opacos y minerales pesados como turmalinas y circones) incluido dentro de una matriz arćillosa teñida por oxihidróxidos de hierro. Ambos componentes (esqueleto y matriz) presentan procesos de disolución de sus minerales silíceos e inicio de procesos de neoformación de otros nuevos, sobre todo arcillas (Fig. 5).

La variedad Marrón (Figs. 3 y 4b) domina en la parte baja del nivel Medio de este afloramiento. Presenta el mismo contraste de colores que la variedad anterior pero con tonalidades más atenuadas (ocres y marrones; Tabla 1). Son matcriales bastante compactos (Tabla 2), ya que desde el punto de vista
Chemical characterisation of the five varieties of stone identified consisted in determining their major elements. To accomplish this, the samples were subjected to attack in acid medium $\left(\mathrm{HNO}_{3}+\mathrm{HF}\right)$ under pressure in a microwave digestor (MILESTONE ML21200) and the solutions thus obtained were buffered with boric acid. Identification of elements was achieved by ICP plasma emission, using a PERKIN-ELMER model Plasma II apparatus.

\section{RESULTS AND DISCUSSION.}

The results obtained point to the existence of a clear separation among the five varieties of stone proposed (Red, Brown, Striped, Nodular and White). In the "Las Canteras" outcrop, these varieties form part of sedimentary facies that have been transformed by diagenetic processes. These facies are interdigitated, both laterally and vertically, meaning that although they are located in a defined space within the outcrop the varieties of stone do not have clear borders separating them. Thus, their extraction is limited to the length and thickness of the sedimentary facies, in question (Fig. 3).

\section{Macroscopic and microscopic characteristics}

The Red variety appears in the basal zone, coinciding with the Lower Level of the "Las Canteras" outcrop and with the original sandy materials (Figs. 3 and 4a). This is massive sandy mud displaying sharp colour contrasts (reds and greens), originated by hydromorphic processes (Table 1). It is a crumbly material (Table 2) such that rather than for construction the local inhabitants have tended to use it in the ceramics industry. Under both the petrographic and scanning electron microscopes, it is seen to be formed by a siliceous material with a skeleton of metamorphic origin (mono- and polycrystalline quartzes, feldspars, fragments of chloroschists and micaschists, illites/muscovites, opaque minerals and heavy minerals such as tourmalines and zircons) embedded within a clayey matrix stained by iron oxihydroxides. Both components (skeleton and matrix) exhibit processes of dissolution of their siliceous minerals and the beginning of processes of neoformation of other minerals, mainly clays (Fig. 5).

The Brown variety (Figs. 3 and $4 b$ ) dominates the lower part of the Middle Level of this outcrop. It displays the same colour contrasy as the previous variety but with more attenuated colours (ochres and browns) (Table 1). The materials are fairly compact (Table 2), since under the microscope they display 


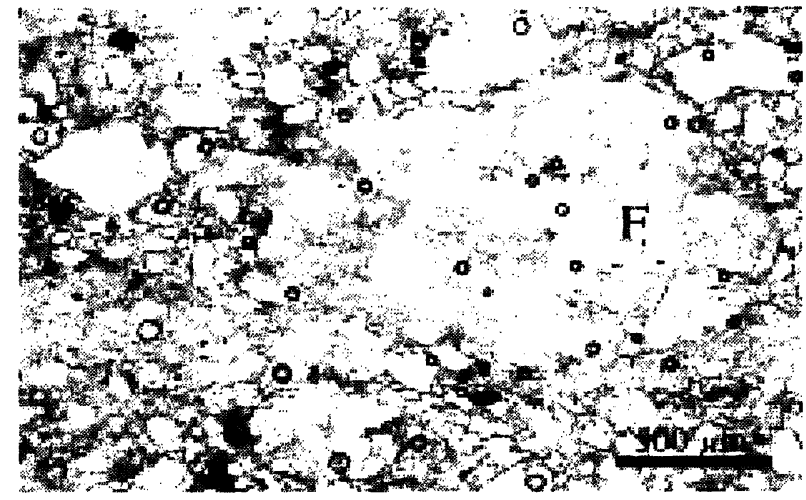

Figura 5.- Aspecto petrógráfico en luz natural de la variedad Roja. El feldespato $(F)$ se está alterando a arcilla en su interior.

Figure 5.- Petrographic aspect in one nicol of the Red lariety of stone Inside, the feldspar $(F)$ is seen to be weathering to clay.

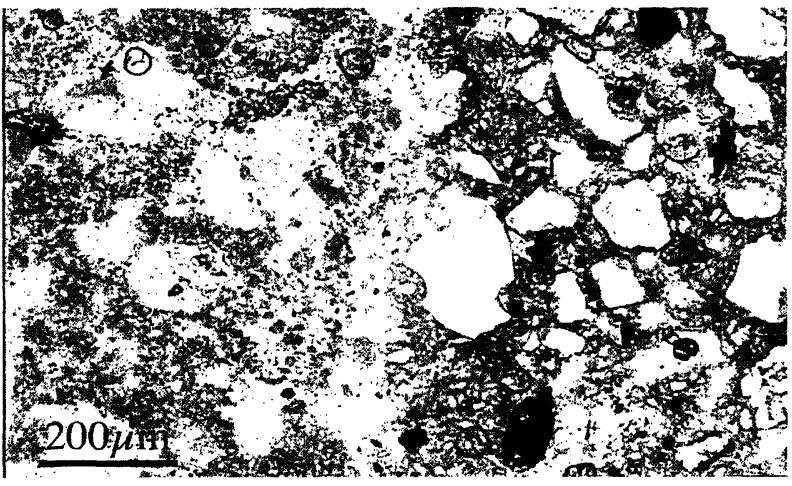

Figura 7. - Aspecto petrográfico en luz natural de la variedad Rayada. En la parte izquierda de la imagen. el esqueleto es escaso, y aparecen la dolomita y la palygorskita mezcladas y formando una masa turbia. Por el contrario, en la parte derecha persiste el material silíceo original (esqueleto y matriz).

Figure7.- Petrographic aspect in one nicol of the Striped variety of stone. At the left of the image, the skeleton is scant and the dolomite and the palygorskite appear mixed, forming a cloudy mass. By contrast, the original siliceous material (skeleton and matrix) appear. at the right.

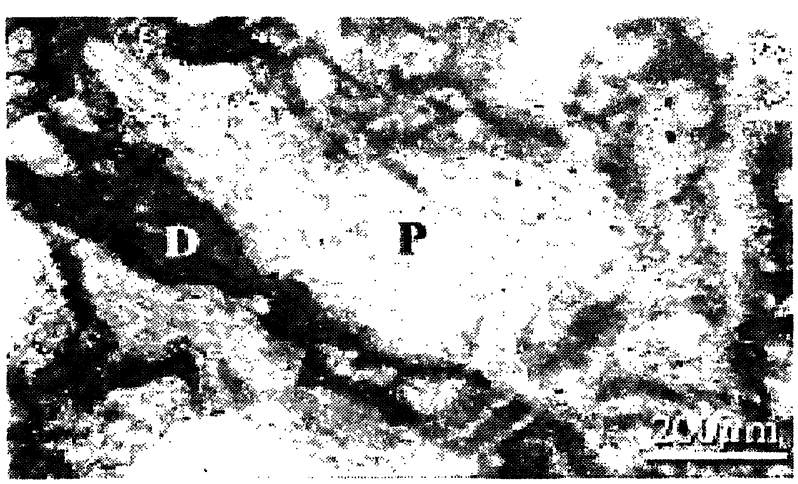

Figura 9. - Aspecto petrográfico en luz natural de la variedad Blanca fina. En esta variedad el esqueleto es escaso frente al amplio dominio de los plasmas arcilloso (P) y dolomítico (D). Ambos plasmas aparecen mezclados, sin ordenamiento alguno.

Figure 9.- Petrographic aspect in one nicol of the Fine White variets of stone. In this variety the skeleton is scant in comparison with the abundance of the clavey (P) and dolomitic (I)) plasmas. Both of these appear mixed, with no ordering.

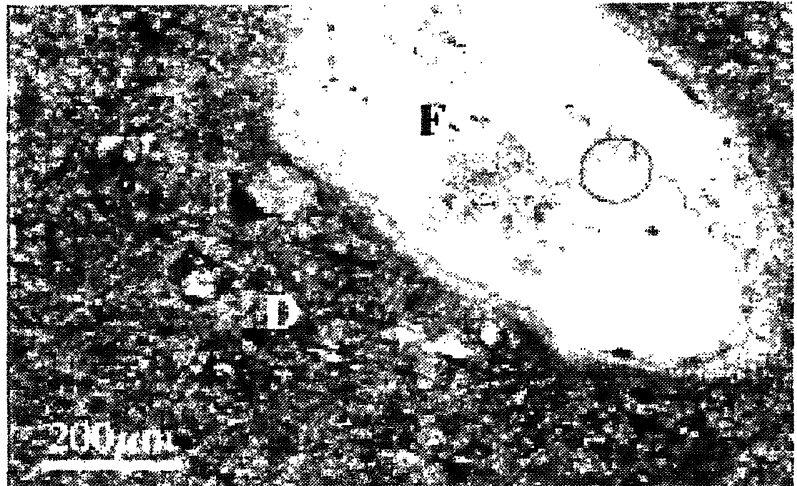

Figura 6.- Aspecto petrográfico en luz. natural de la variedad Marrón. El escaso esqueleto silíceo (F) que queda. está siendo reemplazado en sus bordes por el cristaliplasma dolomítico (D).

Figure 6.- Petrographic aspect in one nicol of the Brown variety of stone. The scant $(F)$ siliceous skeleton that remains is being replaced at the rims by the (D) dolomitic crystalliplasma.

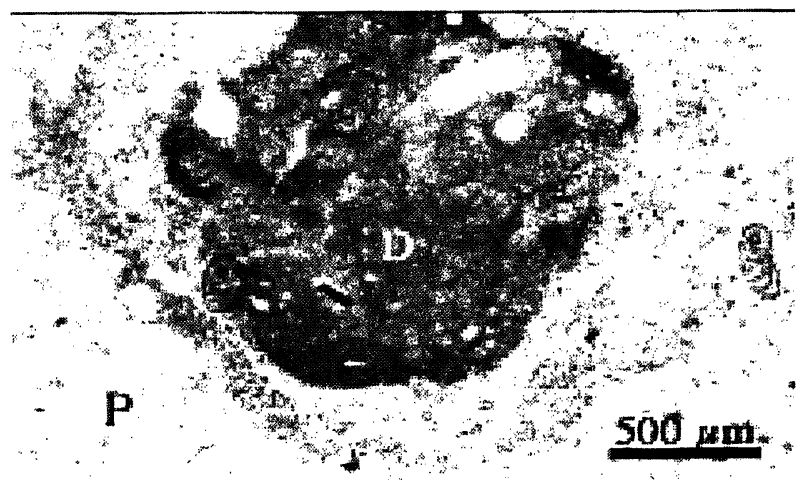

Figura 8.- Aspecto petrográfico en luz natural de la variedad Nodular. Los nódulos de dolomita (D) aislados dentro del argiliplasma palygorskítico (P) son muy típicos en esta variedad.

Figure 8.- Petrographic aspect in one nicol of the Nodular variety of stone. The nodules of dolomite (D) isolated inside the palygorskite argilliplasma $(P)$ are very typical of this variety of stone.

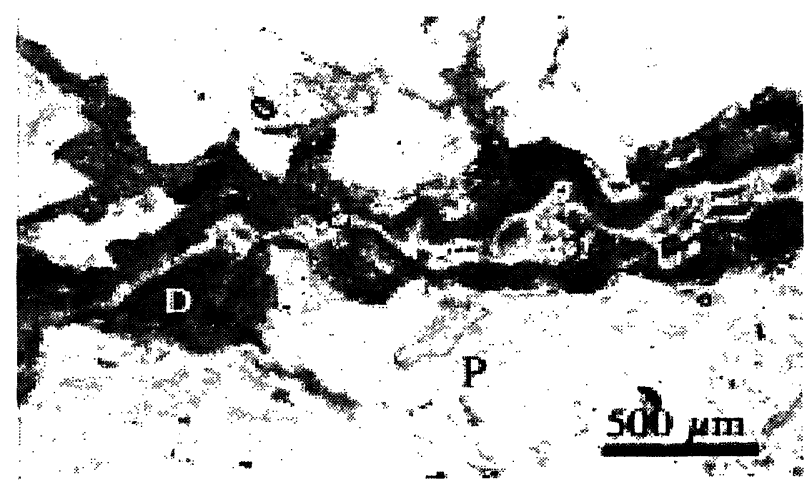

Figura 10.- Aspecto petrográfico en luz. natural de la variedad Blanc: gruesa. En esta variedad el esqueleto es abundante y está rodeado por el argiliplasma palygorskítico (P). La dolomita sólo aparece como venas (D) dentro de esta arcilla.

Figure 10. Petrographic aspect in one nicol of the coarse White variets of stone. In this variets, the skeleton is abundant and is surrounded by the palygorskite argilliplasma (P). The dolomite only appears as reins (I)) inside this clas: 
microscópico, presentan encostramientos carbonatados de tipo dolomítico donde los silicatos originales aparecen como componentes relictos (Fig. 6). Esta dolomita es rica en $\mathrm{CaO}(37,36 \%)$ y $\mathrm{MgO}(25,34 \%)$, pero también tiene cantidades significativas de impurezas tales como: $\mathrm{SiO}_{2}(18,04 \%), \mathrm{Al}_{2} \mathrm{O}_{3}(15,55 \%)$ y $\mathrm{K}_{2} \mathrm{O}(2,66 \%)$, consecuencia del reemplazamiento de los silicatos originales. No es una variedad que abunde niucho, por lo que su utilización en construcción ha sido y es muy limitada.

La variedad Rayada (Figs. 3 y 4c) aparece en la parte alta del nivel Medio y se trata de una arenisca con una amplia gama de colores (rojos-ocres y grises-verdes; Tabla 1 ) que presenta un enrejado poligonal de color blanco. Su estudio microscópico revela la coexistencia de los materiales silíceos originales con los carbonatos diagenéticos (Fig. 7). Sc observa la existencia de pequeñas zonas relictas donde hay un esqueleto formado por clastos silíceos incluido en una matriz. arcillosa, y otras zonas, donde este esqueleto es muy escaso y la matriz está recmplazada por un cristaliplasma dolomítico de aspecto microcristalino. Ambos tipos de materiales aparecen atravesados por venas más o menos horizontales, de tamaño variable, composición carbonatada y aspecto grumoso. Estas venas constituyen un enrejado poligonal muy llamativo a simple vista, y que atribuimos a procesos freáticos posteriores a las transformaciones diagenéticas sufridas por las areniscas silíceas originales. El aspecto de esta variedad pétrea que aparece en la base de las canteras, la hace inconfundible en las fachadas de los edificios históricos de Ciudad Rodrigo. Sus propiedades hídricas aparecen en la Tabla 2.

La variedad Nodular (Figs. 3 y 4d) se localiza en la base del nivel Superior, interdigitada con las facies finas de la variedad siguiente, la variedad Blanca. Muestra un color gris-verde dominante (Tabla 1), salpicado de manchas nodulares de colores llamativos (rosas, blancos, rojos, etc.). Los microscopios petrográfico y electrónico muestran un sedimento fino (fangos arenosos y arenas finas) constituido por un escaso esqueleto relicto de minerales silíceos incluido dentro de un argiliplasma dominante. Esta nueva arcilla es una palygorskita de largas fibras, producto de los procesos diagenéticos que afectan a esta parte alta del afloramiento. La palygorskita sustituye al carbonato dolomítico preexistente (Tabla 3), el cual aparece relegado a simples formas nodulares y con una composición química rica en $\mathrm{CaO}$ y empobrecida en $\mathrm{MgO}$ (Fig. 8). Este tipo de piedra, relativamente blando (Tabla 2), también puede reconocerse fácilmente en los paramentos de los edificios de la ciudad.

La variedad Blanca (Fig. 3) se encuentra coronando el afloramiento y es el material pétreo que más abunda en dolomitic concretions and crusts in which the original silicates appear as relict components (Fig. 6). This dolomite is rich in $\mathrm{CaO}(37.36 \%)$. and $\mathrm{MgO}(25.34 \%)$, although it also has considerable amounts of impurities, such as $\mathrm{SiO}_{2}(18.04 \%), \mathrm{Al}_{2} \mathrm{O}_{3}(15.55 \%)$ and $K, O(2.66 \%)$, deriving from the original replaced silicates. It is not a very abundant variety and hence its use in construction has been very limited.

The Striped lariety (Figs. 3 and 4c) appears at the top) of the middle level and is a sandstone with a broad range of colours (reddish-ochres and greenish-greys; Table 1) and displays a white polygonal lattice. Under the microscope it is possible to observe the coexistence of the original siliceous materials with the diagenetic carbonates (Fig. 7). These contain a skeleton formed by siliceous clasts embedded in a clayey matrix. There are also other zones in which the skeleton is very scant and the matrix has been replaced by a dolomitic crystalliplasma with a microcrystalline aspect. Both types of material are crossed by more or less horizontal veins, varying in size, with a carbonate composition and a lumpy aspect. Under the naked eye, these veins form a very striking polygonal lattice, which we attribute to phreatic processes that occurred after the diagenetic transformations undergone by the original siliceous sandstones. The aspect of this variety of stone appearing at the base of the quarries makes it unmistakable on the walls of the historical buildings in Ciudad Rodrigo. Their hydric properties are show'n in the Table 2.

The Nodular variety (Figs. 3 and 4d) is found at the base of the upper level, interdigitated with the finegrained facies of the next variety (White). It displays a dominant greenish-grey colour (Table 1), spattered with nodular stains in striking colours (pinks, white, reds, etc). Under the petrographic and electron microscope, a fine sediment (sandy muds and fine sands) comprising a scant relict skeleton of siliceous minerals embedded within a dominant argilliplasma can be seen. This new clay is a long-fibered palygorskite, the product of the diagenetic processes affecting this part of the outcrop. The palygorskite replaces the preexisting dolomitic carbonate (Table 3), which is relegated to simple nodular forms (Fig. 8) with a chemical composition rich in $\mathrm{CaO}$ and imporerished in $\mathrm{MgO}$. This type of stone, relatively soft (Table 2): can also be recognised easily on the walls of the buildings of the city.

The White variety (Fig. 3) is found at the top of the outcrop and is the most abundant stone variety in the 


\section{TABLA 1/TABLE}

Análisis del color de las variedades pétreas estudiadas

(Colour analysis of the varieties of stone studied)

\begin{tabular}{|c|c|c|c|c|}
\hline & \multicolumn{3}{|c|}{ Coordenadas cromáticas / Chromatic coordinates } & \multirow{2}{*}{$\begin{array}{l}\text { Cartas de colores de Munsell } \\
\text { Munsell colour charts }\end{array}$} \\
\hline & $\mathrm{L}$ & a & b & \\
\hline ROJA / RED & 63,58 & 2,30 & 17,24 & 7.5YR 7/6-7/8 (amarillo rojizo/reddish yellow) \\
\hline $\begin{array}{l}\text { MARRÓN } \\
\text { BROWN }\end{array}$ & 64,51 & 2,45 & 17,54 & $\begin{array}{l}\text { 10YR 7/4-7/6 (marrón muy pálido-amarillo / very pale } \\
\text { brown-yellow) }\end{array}$ \\
\hline $\begin{array}{l}\text { RAYADA } \\
\text { STRIPED }\end{array}$ & 72,45 & 0,08 & 10,61 & Multicobr /Multicolour \\
\hline $\begin{array}{l}\text { NODULAR } \\
\text { NODULAR }\end{array}$ & 72,39 & $-0,51$ & 9,05 & $\begin{array}{lll}\text { Arcilla /Clay } & 5 Y 7 / 1 \quad \text { ( gris claro/ light gray) } \\
\text { Nódulo /Nodule } & 10 \mathrm{YR} \quad 8 / 4 \quad \text { (marrón muy pálido/very } \\
\text { pale brown) } & & \end{array}$ \\
\hline $\begin{array}{l}\text { BLANCA FINA } \\
\text { FINE WHITE }\end{array}$ & 76,23 & $-0,29$ & 7,25 & 5Y 8/1 (blanco /white) \\
\hline
\end{tabular}

TABLA 2/TABLE 2

Propiedades hídricas de las cinco de las variedades pétreas identificadas como «Areniscas de Ciudad Rodrigo» (Hydric properties of the five varieties of stone identified as «Ciudad Rodrigo Sandstones»)

\begin{tabular}{|c|c|c|c|c|c|c|}
\hline & ROJA/RED & $\begin{array}{l}\text { MARRÓN } \\
\text { BROWN }\end{array}$ & $\begin{array}{l}\text { RAYADA } \\
\text { STRIPED }\end{array}$ & $\begin{array}{l}\text { NODULAR } \\
\text { NODULAR }\end{array}$ & $\begin{array}{l}\text { BLANCA FINA } \\
\text { FINE } \text { WHITE }\end{array}$ & \\
\hline Porosidad Total /Total porosity & 30,38 & 17,22 & 27,70 & 28,92 & 21,74 & $\%$ \\
\hline Porosidad Libre/Free Porosity & 27,27 & 16,06 & 24,46 & 26,92 & 19,97 & $\%$ \\
\hline Coef. de absorción/Coeff of absorption & 89,77 & 93,06 & 88,29 & 93,39 & 91,92 & $\%$ \\
\hline Densidad ReaVReal Density & 2,64 & 2,72 & 2,68 & 2,66 & 2,72 & $\mathrm{~g} / \mathrm{cm}^{3}$ \\
\hline Densidad Aparente/Appanent Density & 1,84 & 2,25 & 1,94 & 1,89 & 2,13 & $\mathrm{~g} / \mathrm{cm}^{3}$ \\
\hline $\begin{array}{l}\text { Coef. imbibición por inmersión totalCoeff. } \\
\text { of imbibition by total immersion }\end{array}$ & 16,16 & 7,38 & 12,47 & 16,03 & 10,47 & $\%$ \\
\hline $\begin{array}{l}\text { Coef absorción capilar/Coeff. of capillary } \\
\text { absorption }\end{array}$ & $20 \times 10^{-4}$ & $8 \times 10^{-4}$ & $15 \times 10^{-4}$ & $19 \times 10^{-4}$ & $15 \times 10^{-4}$ & $\mathrm{~g} / \mathrm{cm}^{2} \mathrm{~s}^{0.5}$ \\
\hline Permeabilidad/Permeability & $2,8 \times 10^{-4}$ & $2,3 \times 10^{-4}$ & $3,3 \times 10^{-4}$ & $2,6 \times 10^{-4}$ & $1,7 \times 10^{-4}$ & $\mathrm{~kg} / \mathrm{cm}^{3} \mathrm{~s}$ \\
\hline
\end{tabular}

\section{TABLA 3/TABLE 3}

Análisis químicos puntuales (SEM) realizados a una fibra de palygorskita y a un cristal de dolomita, respectivamente, dentro de la variedad pétrea Nodular

(Chemical analyses (SEM) of a fibre of palygorskite and a crystal of dolomite, respectively, within the Nodular variety of stone)

\begin{tabular}{|c|c|c|}
\hline & $\begin{array}{l}\text { Arcilla palygorskitica / Palygorskite } \\
\text { clay }\end{array}$ & Dolomita / Dolom ite \\
\hline $\mathrm{SiO}_{2}$ & $68,91-69,02 \%$ & $29,72 \%$ \\
\hline $\mathrm{Al}_{2}$ & $10,38-14,56 \%$ & $4,26 \%$ \\
\hline $\mathrm{MgO}$ & $7,98-10,36 \%$ & $17,38 \%$ \\
\hline $\mathrm{FeO}$ & $4,96-10,65 \%$ & $2,70 \%$ \\
\hline $\mathrm{K}_{2} \mathrm{O}$ & $0,96-1,00 \%$ & - \\
\hline $\mathrm{CaO}$ & $0,13-0,46 \%$ & $45,40 \%$ \\
\hline
\end{tabular}


las canteras. Incluye tanto facies arenosas (facies finas; Fig. 4c) como conglomeráticas (facies gruesas; Fig. 4f), altamente compactadas (Tabla 2). En ambos casos, muestran colores blancos y/o grises (Tabla 1). La facies fina de esta variedad Blanca aparece interdigitada con la variedad anterior puesto que ambas forman parte de antiguas llanuras de inundación. También, este tipo de facies sería el constituyente principal de la desaparecida cantera de "San Juan", limítrofe con la cantera de "Sto. Domingo" y donde aparece junto a la facies gruesa. Por su parte, la facies gruesa se encuentra configurando cuerpos canalizados bien definidos y solapados entre sí, que se corresponden con antiguos sistemas fluviales de carácter episódico y turbulento.

Desde el punto de vista microscópico pueden destacarse dos cosas dentro de esta variedad Blanca:

1) En el caso de que el sedimento sea fino, el esqueleto que aparece es escaso y formado por pequeños clastos de minerales resistentes (cuarzos y feldespatos). En torno a este esqueleto se identifican dos tipos de plasma, el argiliplasma palygorskítico y el cristaliplasma dolomítico. Este último puede llegar a ser dominante en la variedad pétrea y aparece en forma de venas y/o pequeños nódulos relictos de color blanco o rojizo, que vistos al microscopio se tornan de aspecto sucio y microcristalino (Fig. 9).

2) En el caso de que el sedimento sea un conglomerado, el esqueleto lo componen clastos de gran tamaño de cuarzo, cuarcita, esquistos, pizarras, etc, incluidos en un argiliplasma palygorskítico. El cristaliplasma carbonatado es escaso, apareciendo tan sólo como venas relictas (Fig. 10). Por el contrario, la palygorskita es dominante y aparece como una densa masa fibrosa desestabilizada y, debido a ello, con una importante porosidad secundaria intergranular.

Tanto en la actualidad como en el pasado, la variedad Blanca, en su facies más fina es, y ha sido, el tipo de piedra más demandado y, por consiguiente, el más apreciado para la construcción en Ciudad Rodrigo. Se puede decir que es la variedad más representativa y detectada en todos los monumentos de la ciudad. El por qué de ello puede ser muy simple: a) por su atractivo color blanco salpicado de diversas tonalidades rosas o rojas, b) porque es la primera facies que aparece en la cantera al coincidir esta última con la parte alta del perfil diagenético, c) por presentar una textura fina, suave y homogénea que facilita su trabajado y labrado, y d) por tener una alta dureza y compactación.

\section{Difracción de Rayos X (XRD) y Análisis Térmicos (DTA-TG)}

Ambas técnicas corroboran la composición mineralógica detectada anteriormente a través del quarries. Its includes both sandy (Fig.4e) and conglomeratic (Fig.4f) facies, which are very compact (Table 2). In both cases, they show white and/or grey colours (Table 1). The fine facies of this White variety appears interdigitated with the previous variety, since both, form part of ancient flood plains. This type of facies would also be the main component of the now" non-existent "San Juan" quarry, next to the "Santo Domingo" one, in which it appears next to the coarse facies. In turn, the coarse facies is well-defined channel bodies, overlapping one another and corresponding to former episodic and turbulent ancient fluvial systems.

From the microscopic point of view, within this White variety there are two striking features:

1) Where the sediment is fine, the skeleton is scant and is formed by small clasts of resistant minerals (quartzes and feldspars). Around this skeleton are two types of plasma: the palygorskite argilliplasma and the dolomitic crystalliplasma. The latter may be dominant in this variety of stone and appears in the form of veins and/or small white or reddish relict nodules that, under the microscope, are turbid and microcrystalline (Fig.9).

2) Where the sediment is a conglomerate, the skeleton is composed of large clasts of quart-, quart-ite, schists, shales etc, embedded within a palygorskite argilliplasma. The carbonated crystalliplasma is scant, appearing only as relict veins (Fig. 10). By contrast, the palygorskite is dominant and appears as a dense destabilised fibrous mass; owing to this, there is an important secondary intergranular porosity.

In its finest facies, the White variety is and has been the type of stone in greatest demand, and hence most used for construction in Ciudad Rodrigo. It can be said to be the most representative variety and the most common in all the monuments of the city. The reasons for this are very simple: a) its attractive white colour spattered with different hues of pink or red; b) it is the first facies to appear in the quarry since this latter coincides with the top of the diagenetic profile; c) its texture is fine and homogeneous, which facilitates its working and dressing, and d) it is very hard and compact.

\section{$X$-Ray Diffraction (XRD) and Thermal Analyses (DTA-TG)}

Both techniques corroborated the mineralogical composition detected previously with the petrographic: 
microscopio petrográfico y el SEM, para cada una de las variedades pétreas identificadas.

La composición mineralógica semicuantitativa obtenida a través del estudio por difracción de rayos $\mathrm{X}$ de la fracción total de los cinco tipos de arenisca puede observarse en la Tabla 4. Las siglas ML engloban un pequeño grupo de minerales arcillosos: illita/moscovita y palygorskita.

La variedad Roja, muestra la gran importancia que tienen los silicatos alterables (ML, clorita y plagioclasa) y los resistentes (cuarzo y feldespato-K) (Tabla 4; Fig. 11a). El mismo estudio realizado a su fracción arcillosa indica que las illitas/moscovitas abundan sobre a las palygorskitas y cloritas, siendo muy reducida la aparición de esmectitas y sepiolitas. La illita/moscovita y la clorita son minerales heredados, mientras que las otras tres son autigénicas o de nueva formación. La aparición de nuevos minerales confirma el inicio de los procesos diagenéticos a nivel de microambientes. Los análisis térmico-diferenciales (DTA) y

termogravimétricos (TG) (Fig. 12a) realizados a la fracción de polvo total de las muestras reflejan esta misma mineralogía, Fig.4a. Las pérdidas de peso registradas en las curvas de TG de la fracción total no superan el $5 \%$ del peso total ensayado, mientras que en los TG de la fracción arcilla, éstas oscilan entre un 13\% y un $18 \%$, de su peso total. En ambos casos, la mayor parte de las pérdidas se producen a temperaturas bajas y medias $\left(<700^{\circ} \mathrm{C}\right)$ de calentamiento, lo que coincide con la pérdida de los distintos tipos de agua que forman parte de la estructura cristalina de los silicatos, principalmente, laminares y fibrosos. and scanning electron microscopes for each of the varieties of stone identified.

The semiquantitative mineralogical composition obtained in the X-ray diffraction study of the total fraction of the five types of stone is shown in Table 4. The letters ML encompass a small set of clayey minerals (illite/muscovite and palygorskite)

The Red variety indicates the great importance of alterable silicates (ML, chlorite and plagioclase) and the resistant ones (quartz and $K$-feldspar) (Table 4, Fig. 11a). The same study carried out on the clayey fraction indicates that illites/muscovites prevail over the palygorskites and chlorites, the appearance of smectites ad sepiolites being very reduced. The illitel muscovite and the chlorite are inherited minerals, whereas the other three are authigenic or due to neoformation. The appearance of new minerals confirms the start of the diagenetic processes at microenvironmental level. The differential thermal (DTA) and thermogravimetric (TG) (Fig. 12a) analyses carried out on the total powder fraction of the samples reflect this same mineralogy, Fig.4a. The weight loss recorded in the TG curves of the total fraction do not surpass 5\% of the total weight assayed, whereas in the TG analyses of the clay fraction this ranges between 13 and $18 \%$ of the total weight. In both cases, most of the losses occur at low and medium heating temperatures $\left(<700^{\circ} \mathrm{C}\right)$, corresponding to the loss of the different types of water forming part of the crystalline structure of the silicates, mainly of the layer and fibrous type

\section{TABLE 4/TABLE 4}

Análisis semicuantitativo por difracción de rayos $\mathrm{X}$ de la fracción de polvo total correspondiente a las variedades pétreas estudiadas

(Semiquantitative analysis by XRD of the total powder fraction corresponding to the varieties of stone studied)

\begin{tabular}{|l|c|c|c|c|c|c|}
\hline & ROJA/RED \% & $\begin{array}{c}\text { MARRON \% } \\
\text { BROWN }\end{array}$ & $\begin{array}{c}\text { RAYADA \% } \\
\text { STRIPED }\end{array}$ & $\begin{array}{c}\text { NODULAR \% } \\
\text { NODULAR }\end{array}$ & \multicolumn{2}{|c|}{ BLANCA/WHITE \% } \\
\hline Cuarzo/Quartz & $50-60$ & $14-19,4$ & $15,3-21,5$ & $30,3-41,1$ & 9,9 & $31,9-33,3$ \\
\hline Dolomita/Dolomite & & $63,3-70$ & $50,5-57,4$ & $6-48,7$ & 75,8 & $6,5-23,5$ \\
\hline Calcita/Calcite & & & $3,8-9,6$ & $1-9,9$ & 1,3 & $4,8-12$ \\
\hline Feldespato K/K Feldspars & $1,7-15,8$ & $0,1-2,6$ & $0,7-7,3$ & $1,9-6,7$ & 1,6 & $5,6-13,4$ \\
\hline Plagioclasa/Plagioclase & $6,8-9.1$ & $0,6-5,5$ & $1,3-2,4$ & $3,2-5,4$ & 0,4 & $1-1,5$ \\
\hline Clorita/Chlorite & $4-5,2$ & $0,9-1,5$ & $0,4-1,5$ & $0,9-1$ & & $0,5-0,6$ \\
\hline ML & $26-32$ & $6,3-9,1$ & $6,8-18,7$ & $12,1-28,8$ & 8,3 & $29,3-32,5$ \\
\hline $\begin{array}{l}\text { Fe Oxihdrox./Fe } \\
\text { Oxyhydrox. }\end{array}$ & $0,7-3,2$ & $1,7-4,2$ & $0,5-1,8$ & $1,1-1,7$ & 2,5 & 1,6 \\
\hline
\end{tabular}

ML (illita/moscovita y palygorskita) (illite/muscovite and palygorskite) 
g)

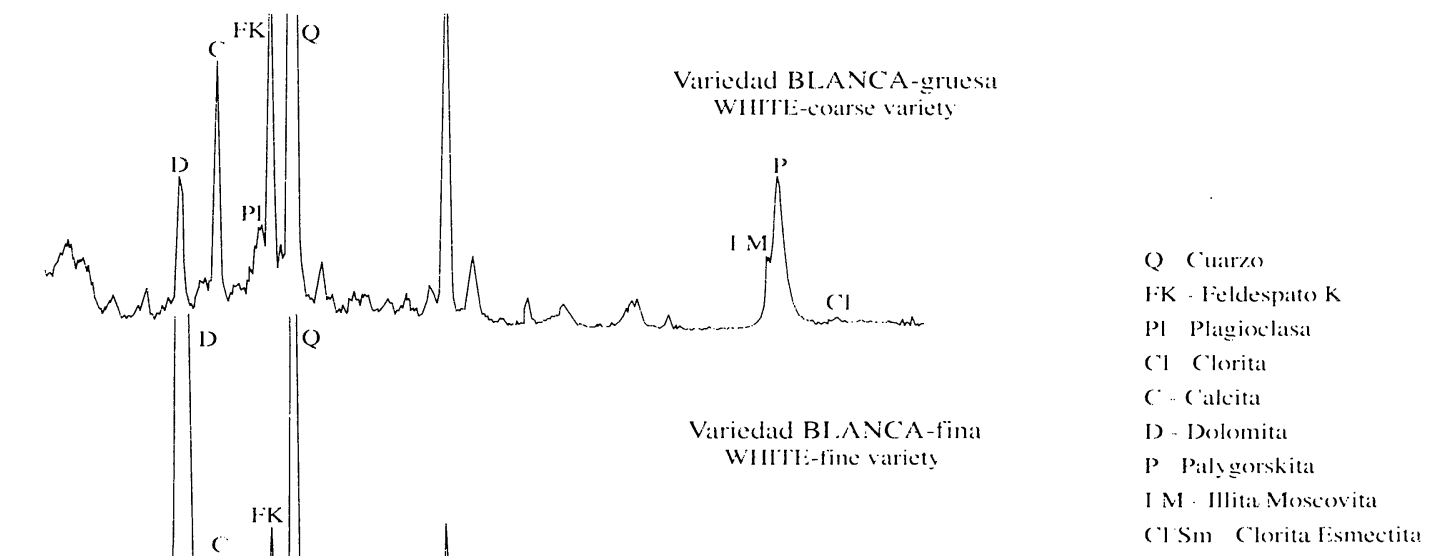

e)

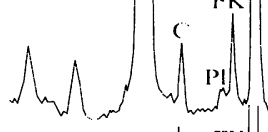

I.MA
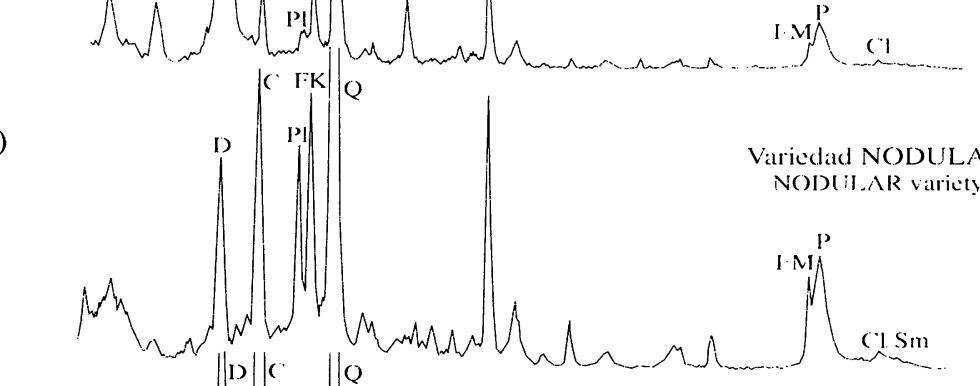

d)
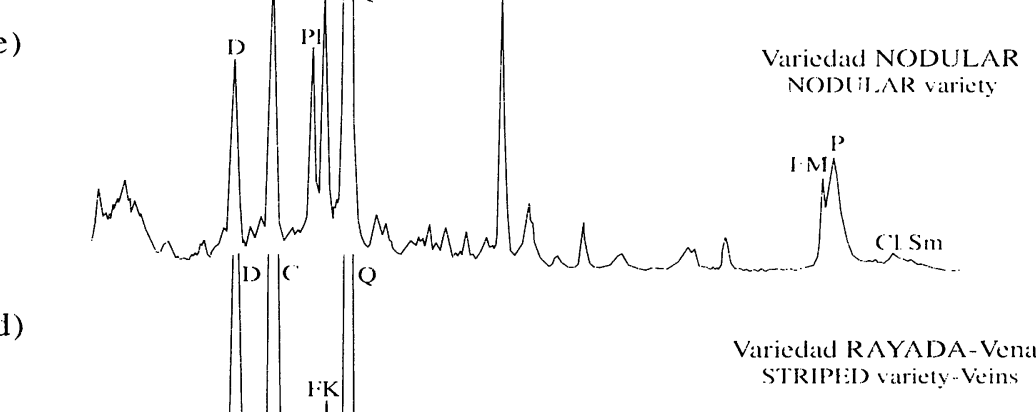

STedad RAYADA-Venas
STRIPISD variety-Veins

$Q \cdot$ Quarts

$\mathrm{I} K \mathrm{~K} \cdot \mathrm{K}$ licklspars

Pl Plag̣ioclaso

(') - Chlorite

C'. ('alcite

D) Dolomite

P Palygorskite

I M - Illite: Muscovit

(1) Sm Chlorite: Smectito

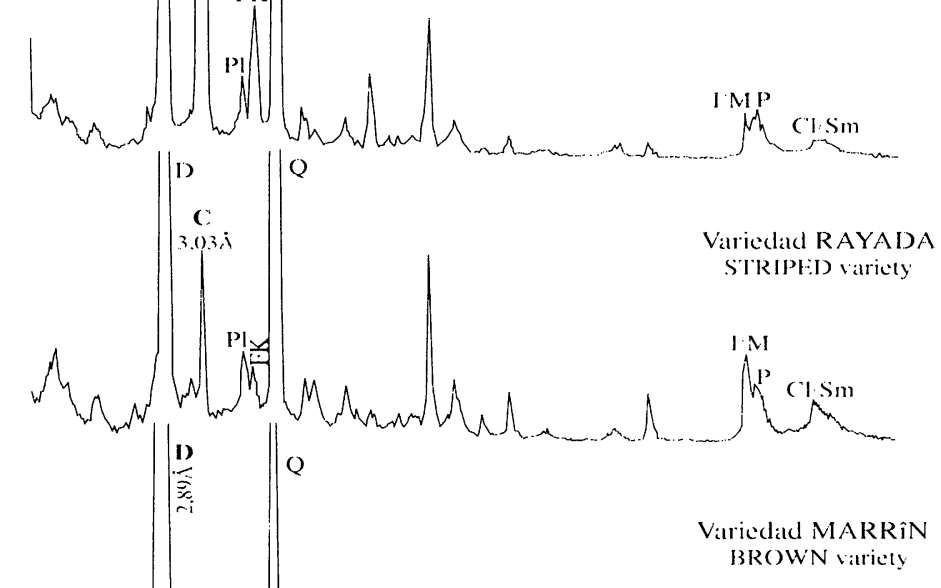

b)

a)
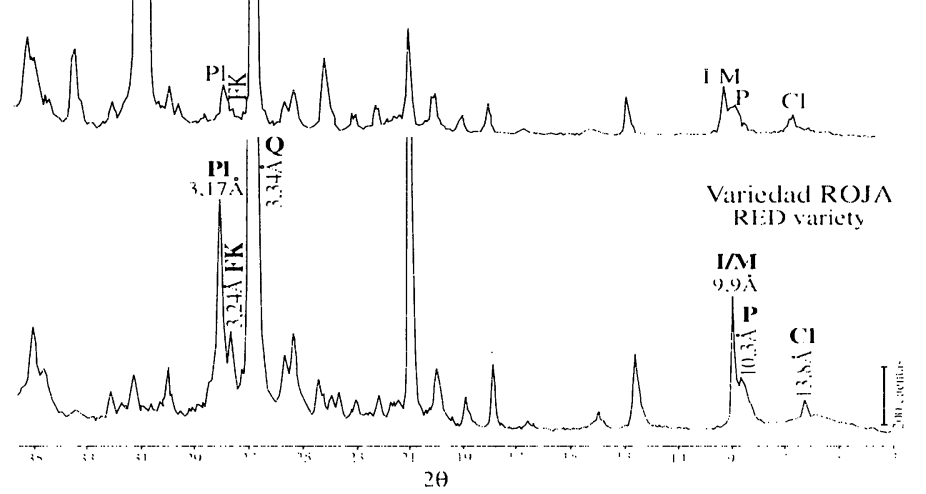

Fignura 11. Difractogramas de rayos X de la fraceion de polvo total de las distintis variediades petrean estudiadas

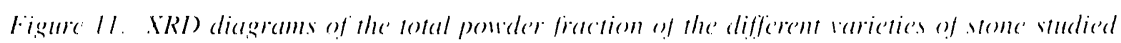


En la variedad Marrón se detectan claramente los procesos diagenéticos sufridos, ya que aparece un nuevo componente mineralógico de naturaleza carbonatada, la dolomita (Tabla 4; Fig. 11b). Al mismo tiempo, se produce un descenso acusado de los componentes silíceos originales y un pequeño incremento del hierro, por inmovilización. En la escasa fracción arcillosa que posee, la palygorskita autigénica supera ligeramente a la illita/moscovita heredada, siendo muy reducida la aparición de cloritas. esmectitas y sepiolitas. El estudio por DTA y TG (Fig. 12b) de la fracción de polvo total de las muestras también reflejan la aparición de este carbonato, indicando además en el caso de los DTA, que se trata de un carbonato rico en Ca y Mg (Fig. 4b). En las curvas de TG de esta fracción total se registran pérdidas en peso de hasta un $31,5 \%$ de su peso total ensayado, equivaliendo el $85 \%$ de esa cantidad, a pérdidas producidas a elevadas temperaturas de calentamiento $\left.(>7())^{\circ} \mathrm{C}\right)$. Ësto indica la presencia de un porcentaje alto en carbonatos, pues son pérdidas debidas al $\mathrm{CO}$, producido en la descomposición térmica de los mismos. Por el contrario, en las curvas de TG de la fracción arcilla, las pérdidas en peso de hasta un 19\% del peso total, son consecuencia, en buen parte, a la pérdida de los distintos tipos de agua que contienen las estructuras cristalinas de los minerales laminares y fibrosos existentes.

La variedad Rayada también muestra altos contenidos en dolomita, pero los silicatos primarios (illita/ moscovita, cuarzo y feldespato-K) persisten en concentraciones ligeramente superiores a las detectadas en la variedad anterior (Tabla 4; Fig. 11c). La característica principal de esta variedad es la aparición de otro nuevo carbonato (calcita) que está relacionado con el enrejado poligonal que presenta. El estudio por rayos $\mathrm{X}$ de las venas blancas (Fig. 11 d) que componen este enrejado muestra un contenido en calcita de hasta un $48 \%$, frente al escaso $20 \%$ que llega a alcanzar la dolomita. En su fracción arcilla sigue dominando la palygorskita autigénica sobre la illita/moscovita y la clorita heredadas. Los análisis de DTA y TG, Figs. 12c y 12 detectan ambos tipos de carbonato con una alta riqueza en Ca (Fig. 12c). En el caso de las venas carbonatadas (Fig. 12d), el pico endotérmico del Mg es insignificante respecto al del Ca, corroborando así la naturaleza cálcica y calcítica de las mismas. Las curvas de TG de la fracción de polvo total registran pérdidas de peso de hasta un $21,5 \%$ del peso total de la muestra ensayada, siendo más del 70\% del total de esa cantidad. consecuencia directa de ka descomposición térmica de los carbonatos a altas temperaturas. En la fracción arcilla. las elevadas pérdidas en peso (>28\%) que acontecen a temperaturas bajas y medias, reflejan la existencia de una alta cantidad de minerales laminares y/o fibrosos en su composición.
In the Brown variety, the diagenetic processes undergone by the stone are clearly visible, since a new carbonated mineralogical component-dolomite-appears (Table 4: Fig. $11 \mathrm{~b})$. At the same time, a sharp decrease can be seen in the original siliceous components and a small increase in iron due to immobilisation. In the scant clay fraction of this variety, authigenic palygorskite slightly surpasses the inherited illite/muscovite, the appearance of chlorites, smectites and sepiolites being very reduced. DTA and TG (Fig. 12b) study of the total powder fraction of the samples also reflects the appearance of this carbonate. also indicating -in the case of the DTA analyses- that the carbonate is rich in $\mathrm{Ca}$ and $\mathrm{Mg}$ (Fig. $\mathrm{II}$ b). In the $T G$ curies of these total powder fractions, weight losses of up to $31.5 \%$ of the total weight assayed were recorded. $85 \%$ of this amount being equiralent to losses produced at high heating temperatures $\left(>700^{\circ}{ }^{\circ}\right)$. This to points to the presence of a high carbonate percentage since the losses are due to the $\mathrm{CO}$, produced in the thermal decomposition of the carbonates. By contrast, in the $T G$ curves of the clay fractions the weight losses of up to 19\% of the total weight are largely a consequence of the loss of the different types of water containing in the crystalline structures of the existing laver and fibrous minerals.

The Striped variety also show's high dolomite contents although the primary silicates (illite/muscovite, quartz and K-feldspar) are still present at concentrations slightly higher than those seen in the previous variety (Table 4. Fig. Ilc). The main characteristic of this variety is the appearance of another new carbonate (calcite), related to the polygonal lattice displayed by the stone. X-ray study of the white veins (Fig. IId) that form this meshwork reveals a content in calcite of up to $48 \%$, as compared with the scant $20 \%$ of dolomite. In its clay fraction, authigenic dolomite continues to predominate over the inherited illite/muscovite and chlorite. DTA and TG, Figs. 12 and 12 d analyses detected both types of carbonate with a high $\mathrm{Ca}$ content (Fig. I2c). In the case of the carbonated veins (Fig. 12d), the endothermal peak of $\mathrm{Mg}$ is insignificant with respect to that of $C$ a, thus corroborating their calcic and calcitic nature. The TG curves of the total powder fraction reveal weight losses of up to $21.5 \%$ of the total weight of the sample assayed, more than $70 \%$ of the total of that amount, being a direct consequence of the thermal decomposition of the carbonate at high heating temperatures. In the clay fraction, the pronounced weight losses (>28\%) occurring at high and medium temperatures reflect the existence of a large amount of laver and or fibrous minerals in it. 

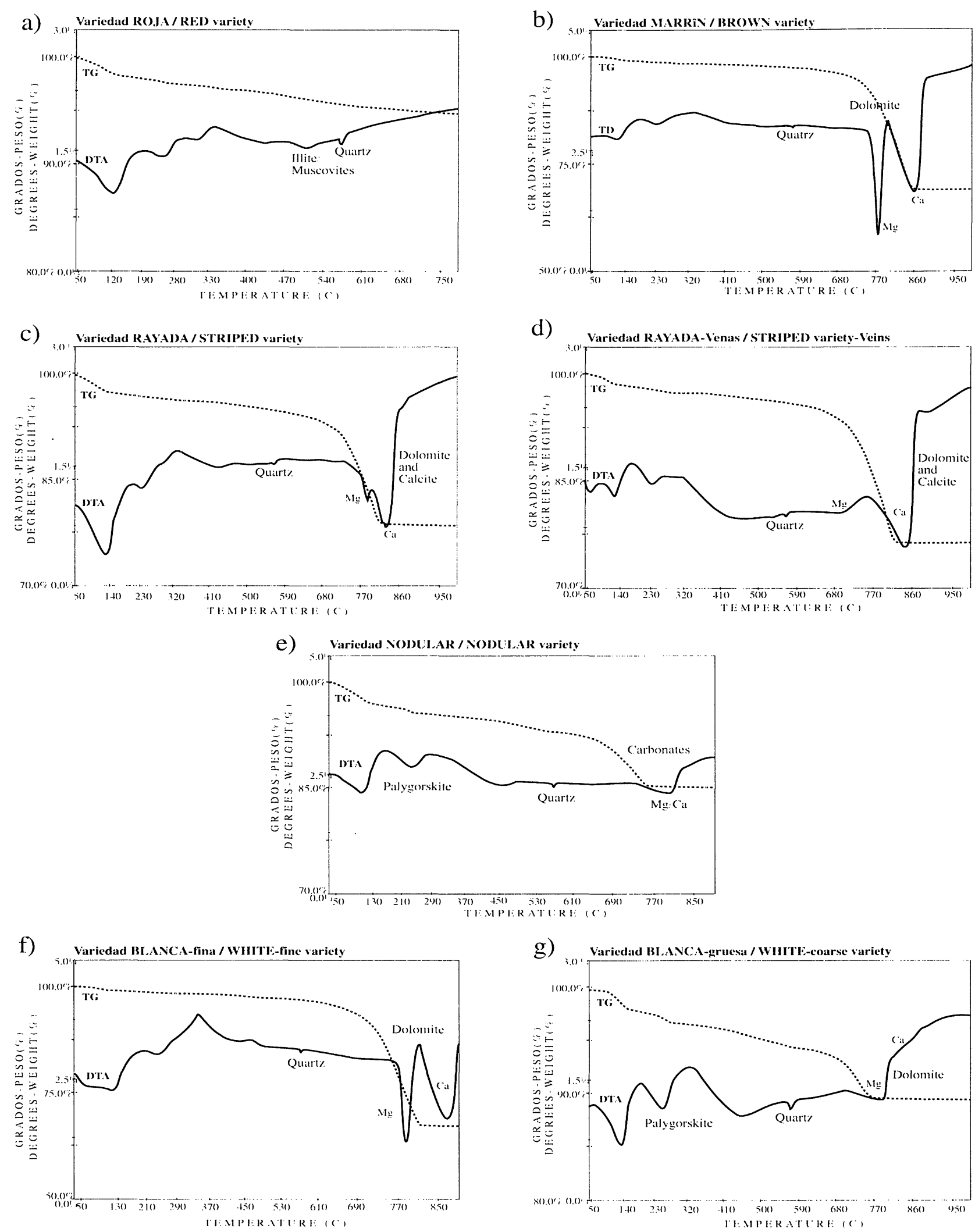

Figura 12.- Curvas de TD y TG correspondientes a la fracción de polvo total de las cinco variedades pétreas identificadas en los tres niveles del afloramiento de "Las Canteras".

Figure 12.- DTA and Thi curves corresponding to the total powder fraction of the fire varieties of stone identified in the three levels of the "Las Canteras" outcrop. 
En la variedad Nodular se detecta otro paso en la evolución de los procesos de alteración diagenéticos que afectan a estos materiales. I os diagramas de DRX de la fracción de polvo total de las muestras (Tábla 4: Fig. 1 le), reflejan el auge de los silicatos englobados en las siglas ML. sobre todo el de la palygorskita. Sin embargo, los carbonatos sufren un descenso generalizado, localizándose tan sólo concentraciones importantes en los nódulos que definen esta variedad pétrea. La fracción arcillosa que más ampliamente domina en esta variedad pétrea es la palygorskita. Los análisis de DTA y TG (Fig. 12e) de la fracción total. Fig. 1 le también confirman el aumento de esta arcilla $(6.4 \% \text { a }<700)^{\circ} \mathrm{C}$, del peso total de la cantidad ensayada $)$ y la caída de los carbonatos $\left(7,15 \%\right.$ a $\left.>7(0){ }^{\circ} \mathrm{C}\right)$. En la fracción arcilla, las curvas de TG registran pérdidas de peso a temperaturas bajas y medias, de hasta un 17,4\% de su peso total, correspondiendo. en su mayor parte. a la eliminación de los diferentes aguas que contienen las palygorskitas existentes. Las curvas de estos DTA y TG son muy típicas de la palygorskita.

La variedad Blanca presenta grandes diferencias según corresponda a la facies fina o gruesa. En su facies fina (Tabla 4; Fig. 11f), los silicatos aparecen en cantidades despreciables frente al amplio dominio de la dolomita. Por el contrario, en su facies gruesa (Tabla 4: Fig. 11 g) los silicatos adquieren gran importancia, al ser éstos los componentes principales de los cuerpos conglomeráticos que la forman. Son los silicatos resistentes (cuarzo y feldespato-K) los que más abundan como componentes del esqueleto, mientras que los silicatos alterables (plagioclasa y clorita) quedan relegados a apariciones sin consideración. Cabe destacarse el gran incremento que experimenta el grupo ML dentro de estos silicatos alterables, sobre todo la palygorskita ya que constituye el argiliplasma que rodea al esqueleto. En ambas facies. la fracción arcilla que abunda es la palygorskita. Los análisis térmicos (DTA-TG) (Figs. 12f y 12g) confirman todos estos resultados, Figs. 11 f y $11 \mathrm{~g}$. En los análisis de TG de la fracción de polvo total de las muestras, la elevada pérdida en peso (hasta un $33 \%$ de su peso total) que experimentan las facies más finas, indica un alto contenido en carbonatos ( $88 \%$ ). Pero no ocurre lo mismo en la facies gruesa, donde las mayores pérdidas se deben a las altas cantidades de palygorskita que aparece. Los análisis de DTA y TG de la fracción arcilla, también reflejan la alta presencia que tiene la palygorskita en esta variedad Blanca.

\section{Analisis químicos de elementos mayores}

Los resultados de los análisis químicos realizados a diversas muestras representativas de las cinco variedades pétreas, aparecen recogidos en la Tabla 5. Del estudio de la misma se desprende lo siguiente:
In the Nodular variety, another step in the evolution of the diagenetic alteration processes affecting the materials can be appreciated. The XRI) diagrams of the total powder fraction of the samples (Table 4; Fig. Ile) show the increase in the silicates referred to under the initials of $M L$, above all that of palygorskite. However, the carbonates undergo a generalised decrease. important concentrations being seen only in the nodules that define this variety of stone. The clay fraction that most predominates in this variety is palygorskite. DTA and TG (Fig. I2e) analyses of the total powder fraction, Fig. Ile also confirm the abundance of this clay $(6.4 \%$ at $<700$ " $\mathrm{C}$. of the total weight of the amount assayed) and the fall in carbonates $\left(7.15 \%\right.$ at $\left.>700{ }^{\circ} \mathrm{C}\right)$. In the clay fractions. at low and medium temperatures, the TG curves reflect weight losses of up to $17.4 \%$ of the total weight of the samples, mostly corresponding to the removal of the different types of water contained in the palygorskites present. The curves of these DTA and TG analyses are highly typical of palygorskite.

The White variety varies considerably, depending on whether one is dealing with the fine or coarse facies. In its fine facies (Table 4, Fig. IIf), silicates appear in negligible quantities in comparison with the strong predominance of dolomite. By contrast, in its coarse facies (Table 4, Fig. $11 \mathrm{~g}$ ) silicates acquire considerable importance since they are the main components of the conglomeratic bodics forming the facies. The most abundant components of the skeleton are resistant silicates (quarts and $K$-feldspar), whereas the appearance of alterable silicates (plagioclase and chlorite) is negligible. (Of interest is the strong increase undergone by the MI. group in these alterable silicates, above all palygorskite since it forms the argilliplasma surrounding the skeleton. In both types of facies, the predominant clay fraction is palygorskite. The thermal analyses (DTA-TG) (Figs. I2f and $12 \mathrm{~g}$ ) confirm all these findings, Figs. IIf and IIg. In the TG analysis of the total powder fraction of the samples, the strong weight loss (up to $33 \%$ of the total weight of the sample) undergone by the finest facies indicates a high carbonate content ( $\$ 88 \%)$. However, this is not the case in the coarse facies, in which the greatest losses are due to the high amounts of palygorskite. The DTA and $T G$ analyes of the clay fraction also reflect the elevated presence of palygorskite in this variety of stone

\section{Chemical analysis of major elements}

The results of the chemical analyses carried out on several representative samples of the five varieties of stone are shown in Table 5. From these studies the following conclusions ay be drawn: 
Composición química en elementos mayores de las cinco variedades pétreas descritas

(Chemical composition in major elements of the five varieties of stone studied)

\begin{tabular}{|c|c|c|c|c|c|c|c|c|c|c|c|c|c|}
\hline & & $\%$ & $\mathrm{SiO}_{2}$ & $\mathrm{Al}_{2} \mathrm{O}_{3}$ & $\mathrm{Fe}_{2} \mathrm{O}_{3}$ & MnO & MgO & $\mathrm{CaO}$ & $\mathrm{Na}_{2} \mathrm{O}$ & $\mathrm{K}_{2} \mathrm{O}$ & $\mathrm{TiO}_{2}$ & Volatiles & $S($ ppm) \\
\hline \multirow{6}{*}{ 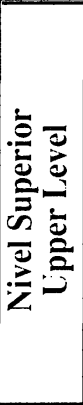 } & \multirow{4}{*}{ 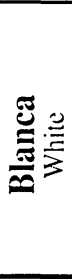 } & $\begin{array}{c}\text { Gruesa } 3 \\
\text { Coarse } 3\end{array}$ & 63,53 & 6,81 & 2,12 & 0.02 & 5.45 & 5,81 & 0,13 & 0.68 & 0.21 & 12,85 & 242 \\
\hline & & $\begin{array}{c}\text { Gruesa } 2 \\
\text { Coarse } 2\end{array}$ & 65,11 & 8,02 & 2,62 & 0.02 & 4.21 & 5.20 & 0,17 & 1,81 & 0.28 & 11,27 & 370 \\
\hline & & $\begin{array}{c}\text { Gruesa } 1 \\
\text { Coarse 1 }\end{array}$ & 76,34 & 8,33 & 1,98 & 0,02 & 2.68 & 0.89 & 0.47 & 1.13 & 0.26 & 5,52 & 310 \\
\hline & & $\underset{\text { Fine } 1}{\text { Fina } 1}$ & 25.84 & 3,39 & 1.04 & 0,03 & 11,88 & 22,96 & 0,10 & 0.84 & 0.20 & 33,57 & 807 \\
\hline & \multicolumn{2}{|c|}{$\begin{array}{c}\text { Nodular } 2 \\
\text { Nodular } 2\end{array}$} & 55,79 & 9,23 & 2.60 & 0.03 & 4,92 & 7.26 & 0.24 & 2,38 & 0,31 & 17,10 & 265 \\
\hline & \multicolumn{2}{|c|}{$\begin{array}{c}\text { Nodular } 1 \\
\text { Nodular | }\end{array}$} & 54,12 & 8,27 & 2,46 & 0.04 & 6.84 & 7,95 & 0.77 & 1,50 & 0.85 & 15,32 & 362 \\
\hline \multirow{5}{*}{ 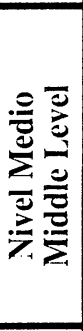 } & \multicolumn{2}{|c|}{$\begin{array}{c}\text { Rayada } 2 \\
\text { Striped } 2 \\
\end{array}$} & 55,79 & 7,44 & 1.86 & 0.02 & 4,92 & 9,54 & 0.49 & 2.20 & 0.28 & 17,29 & 390 \\
\hline & \multicolumn{2}{|c|}{$\begin{array}{c}\text { Rayada } 1 \\
\text { Striped } 1\end{array}$} & 40,84 & 8,78 & 3,07 & 0,04 & 9,24 & 12,69 & 0.27 & 1.86 & 0,59 & 21,76 & 440 \\
\hline & \multicolumn{2}{|c|}{$\underset{\text { Striped-Vein }}{\text { Rayada-Vena }}$} & 35,98 & 5,24 & 1,62 & 0,02 & 6.86 & 22,50 & 0,21 & 2.01 & 0,29 & 24,87 & 567 \\
\hline & \multicolumn{2}{|c|}{$\underset{\text { Brown } 2}{\operatorname{Marr}-\mathbf{n} 2}$} & 40,21 & 6,83 & 2,10 & 0,05 & 9,72 & 14,52 & 0,57 & 1,37 & 0,45 & 23,85 & 610 \\
\hline & \multicolumn{2}{|c|}{$\underset{\text { Brown 1 }}{\operatorname{Marr}-\mathbf{n} 1}$} & 22,28 & 5,58 & 2,60 & 0,06 & 14,81 & 20,47 & 0,10 & 2,88 & 0.25 & 31,70 & 592 \\
\hline \multirow{5}{*}{ 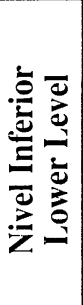 } & \multicolumn{2}{|c|}{ Roja 5 Red 5} & 73,02 & 10,98 & 3,68 & 0.04 & 2,43 & 0,47 & 0,87 & 2,28 & 1,04 & 5.09 & 282 \\
\hline & \multicolumn{2}{|c|}{ Roja 4 Red 4} & 74,99 & 8,99 & 3,83 & 0.02 & 2.60 & 0.24 & 0,58 & 2.34 & 1,08 & 5.08 & 235 \\
\hline & \multicolumn{2}{|c|}{ Roja $3 \operatorname{Red} 3$} & 76,00 & 9,59 & 2,88 & 0.02 & 2.02 & 0,24 & 0,84 & 2.51 & 0,70 & 4,48 & 222 \\
\hline & \multicolumn{2}{|c|}{ Roja $2 \operatorname{Red} 2$} & 71,81 & 10,46 & 4,90 & 0,04 & 2.33 & 0,40 & 0,90 & 2.56 & 1,22 & 5,78 & 165 \\
\hline & \multicolumn{2}{|c|}{ Roja 1 Red 1} & 72,89 & 11,27 & 3,81 & 0.05 & 2.26 & 0.42 & 0,83 & 2,15 & 1,14 & 5,02 & 171 \\
\hline
\end{tabular}

- La varicdad Roja, presenta valores elevados en $\mathrm{SiO}_{2}$, $\mathrm{Al}_{2} \mathrm{O}_{3}$ y $\mathrm{Fe}_{2} \mathrm{O}_{3}$, lo que atribuimos a un alto contenido en filosilicatos de Fe y $\mathrm{Al}$ (p.ej. illitas/moscovitas y cloritas). Este hierro, al ser liberado por hidrólisis, es el que tiñe de color rojo al conjunto del material. Por su parte, la geoquímica del $\mathrm{TiO}_{2}$ es semejante a la del $\mathrm{Fe}_{2} \mathrm{O}_{3}$ por lo que su fuente es la misma que la de este último.

Una parte de este $\mathrm{SiO}_{2}$ y $\mathrm{Al}_{2} \mathrm{O}_{3}$ también queda englobado dentro de los granos de cuarzo y feldespatos que componen el esqueleto de esta variedad pétrea y a los que además hay que añadirles la presencia $\mathrm{Na}_{2} \mathrm{O}$ y $\mathrm{K}, \mathrm{O}$. La existencia de un contenido bastante homogéneo en $\mathrm{MgO}$ suponemos se corresponde, principalmente, con los filosilicatos de tipo clorita y las arcillas fibrosas de tipo palygorskita, presentes ambos en la fracción arcilla. En las cloritas, el Fe y el $\mathrm{Mg}$ comparten los huecos octaédricos.

- Variedad Marrón. El paso del nivel Inferior al Medio supone un gran cambio desde el punto de vista químico. Se produce un gran aporte de carbonatos que provoca: 1) una fuerte disminución del contenido en $\mathrm{SiO}, \mathrm{Al}, \mathrm{O}$.
-The Red variety has high values of $\mathrm{SiO}_{2}, \mathrm{Al}_{2} \mathrm{O}_{3}$ and $\mathrm{Fe}_{2} \mathrm{O}_{3}$; this can be attributed to a high content in phyllosilicates of $F e$ and Al (e.g., illites/muscovites and chlorites). Upon its release by hydrolysis, this iron is responsible for the red colour of the stone. In turn, the geochemistry of $\mathrm{TiO}$, is similar to that of $\mathrm{Fe}_{2} \mathrm{O}_{3}$, such that its source must be the same as that of this latter compound.

Part of the $\mathrm{SiO}$, and $\mathrm{Al}, \mathrm{O}_{3}$ is also encompassed within the grains of quart and feldspars comprising the skeleton of this variety of stone, and to these the presence of $\mathrm{Na}, \mathrm{O}$ and $\mathrm{K}, \mathrm{O}$ should be added. The presence of a fairly homogeneous content of $\mathrm{MgO}$ is assumed to correspond mainly to chlorite-type phyllosilicates and palygorskite-type fibrous clays, both appearing in the clay fraction. In the chorites, Fe and Mg share the octahedral positions.

-Brown variety: The passage fiom the Lower to the Middle Level involves a considerable change from the chemical point of vien. There is a strong presence of (arbonates, which elicits 1 ) a strong decrease in the 
$\mathrm{Fe}_{2} \mathrm{O}_{2}, \mathrm{Na}_{2} \mathrm{O}, \mathrm{K}_{2} \mathrm{O}$ y $\mathrm{TiO} \mathrm{O}_{2}$ y un aumento acusado en $\mathrm{CaO}$ y MgO: 2) un aumento importante en volátiles (CO, y $\left.\mathrm{H}_{2} \mathrm{O}\right)$ y elementos extraños (p.ej. S): y 3) la variación en la relación $\mathrm{SiO}\left(\mathrm{Al}, \mathrm{O}+\mathrm{Fe}, \mathrm{O}_{2}\right)$ a favor del denominador por disminución importante del numerador (por remplazamiento).

- La variedad Rayada de la parte alta del nivel Medio se asimila químicamente a la variedad Marrón. salvo que presenta ligeros descensos en los componentes carbonatados ( $\mathrm{MgO}, \mathrm{CaO}$ y volátiles) y leves ascensos en $\mathrm{SiO}_{2}$ y $\mathrm{Al}_{2} \mathrm{O}_{3}$. Esto corrobora la presencia de ambos grupos de mincrales (carbonatos y silicatos). ya detectados con las técnicas anteriores. La salvedad la marcan las venas del enrejado poligonal que son bastante ricas en calcio ( $\mathrm{CaO}$; Tabla 5). En definitiva. esta piedra es de gran heterogeneidad tanto en su composición química como mineralógica.

- La variedad Nodular supone la base del nivel Superior y en ella se aprecia un aumento relativo del contenido en $\mathrm{Al}_{2} \mathrm{O}_{3}$ ( $y$ más ligero en $\mathrm{Fe}_{2} \mathrm{O}_{3}$ ), y una disminución en el contenido de $\mathrm{CaO}$ y volátiles. Suponemos que estas pequeñas variaciones son debidas al proceso de reemplazamiento de los carbonatos por la palygorskita, cuyos componentes principales son $\mathrm{SiO}_{2}, \mathrm{Al}_{2} \mathrm{O}_{3}$ y $\mathrm{MgO}$.

- La variedad Blanca que corona el nivel Superior. muestra composiciones químicas que difieren enormemente según se trate de su facies fina o gruesa. La facies fina es bastante rica en $\mathrm{MgO}$ y, sobre todo. en $\mathrm{CaO}$, y junto con el alto contenido en volátiles denota su gran riqueza en carbonatos. Por el contrario. la variedad gruesa muestra una composición química baja en carbonatos ( $\mathrm{CaO}, \mathrm{MgO}$ y volátiles) y alta en silicatos ( $\mathrm{SiO}_{2}$ y $\mathrm{Al}_{2} \mathrm{O}_{3}$ ). como consecuencia no sólo de los conglomerados que definen esta facies sino también del argiliplasma palygorskítico que engloba a este conglomerado.

En definitiva, los análisis químicos realizados confirman y reafirman la mineralogía detectada por las técnicas empleadas en el estudio de las cinco variedades pétreas aquí definidas.

\section{CONCLUSIONES}

El exhaustivo estudio realizado al afloramiento de "Las Canteras". permitió identificar una serie de procesos diagenéticos que fueron transformando la química y la mineralogía de la piedra original (variedad Roja) a lo largo de todo el afloramiento. Esto significó transformaciones cada vez más complejas que conllevaron el paso de una mineralogia original múltiple a otra nueva más simple (dolomita y palygorskita: lïg. 1.3). content of SiO , $\mathrm{Al}_{2} \mathrm{O}_{3}, \mathrm{Fe}, \mathrm{O}_{3}, \mathrm{Na}, \mathrm{O}, \mathrm{K}_{2} \mathrm{O}$ and TiO,. and a marked increase in $\mathrm{CaO}$ and $\mathrm{MgO} ; 2$ ) an important increase in rolatiles ( $\mathrm{CO}$, and $\mathrm{H}, \mathrm{O})$ and rare elements (e.g. S): and 3) a rariation in the $\mathrm{SiO}, /\left(\mathrm{Al}, \mathrm{O}_{3}+\mathrm{Fe}_{2} \mathrm{O}_{3}\right)$ ratio owing to an important decline in the numerator due to replacement.

-The Striped variety of the upper part of the middle level is chemically very similar to the Brown variety, although there are slight decreases in the carbonated components ( $\mathrm{MgO}, \mathrm{CaO}$ and volatiles) and slight increases in $\mathrm{SiO}_{2}$ and $\mathrm{Al} \mathrm{O}_{2}$. This confirms the presence of both carbonates and silicates, detected with the techniques used previously: The exception here is the reins of the polygonal lattice, which are quite rich in calcium (CaO). Table 5). In sum, this variety of stone is very heterogeneous as regards both its chemical and mineralogical composition.

-The Nodular variety forms the base of the Upper level and this shows a relative increase in the content of $\mathrm{Al}_{2} \mathrm{O}$; (and a slight increase in $\mathrm{Fe}_{2} \mathrm{O}_{3}$ ), together with a decrease in the content of $\mathrm{CaO}$ and volatiles. We assume that these slight variations must be due to the process of replacement of the carbonates by palygorskite, whose main components are $\mathrm{SiO}_{2}, \mathrm{Al}_{2} \mathrm{O}$ and $\mathrm{MgO}$.

-The White variety rests at the top of the Upper level and has chemical compositions that vary widely depending on whether one is dealing with the fine or coarse facies. The fine facies is fairly rich in $\mathrm{MgO}$ and, above all. $\mathrm{CaO}$. Together with the high content in volatiles this points to its richness in carbonates. By contrast, the coarse variety shows a chemical composition low in carbonates $(\mathrm{CaO}, \mathrm{MgO}$ and rolatiles) and high in silicates ( $\mathrm{SiO}$, and $\mathrm{Al}, \mathrm{O}_{3}$ ). This is a consequence not only of the conglomerates defining this facies but also of the palygorskite argilliplasma encompassing this conglomerate.

In sum, the chemical analyses carried out in the present study confirm and reinforce the mineralogy detected by the techniques used in the study of the five rarieties of stone defined.

\section{CONCLUSIONS}

The in-depth study carried out on the "Las Canteras" outcrop has allowed us to identify a series of diagenetic processes that have gradually transformed the chemistry and mineralogy of the original stone (Red variety) throughout the outcrop. This led to ever-more complex transformations, which in turn involved the passage from a multiple original mineralogy to another simpler one (dolomite and palygorskite, Jig. I.3). 


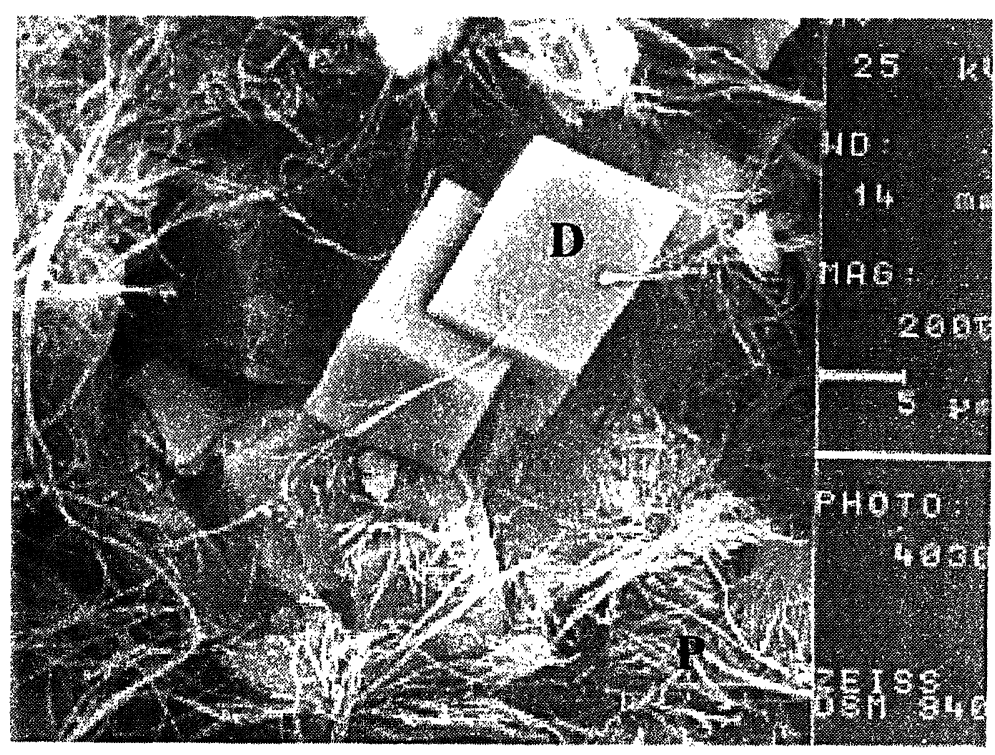

Figura 13.- Aspecto tridimensional al microscopio electrónico de barrido (SEM) de la mineralogía dominante (dolomita-D y palygorskita-P) en las principales variedades pétreas empleadas en la construcción de Ciudad Rodrigo (Rayada. Nodular y Blanca).

Figure 13.- SEM threedimensional aspeet of the predominam mineralogy idolomite. $D$ and palygorskite-P) in the main raricties of stone used in the construction of monumental buildings in Ciudad Rodrigo (Striped. Nodular and White).

Los cambios sufridos por la variedad pétrea original se tradujeron en otras cuatro variedades pétreas (Marrón, Rayada, Nodular y Blanca), claramente definidas entre sí y completamente diferentes a la original. Estas nuevas variedades pétreas presentan una serie de mejoras, tanto en su aspecto y textura como en su compactación y dureza que las hacen deseables para la construcción. Por ello, las gentes de Ciudad Rodrigo han utilizado desde siempre las variedades pétreas más transformadas (Rayada, Nodular y Blanca fina). Esto se debe a las propiedades ventajoṣas que han aportado a su piedra original las transformaciones diagenéticas sufridas.

\section{AGRADECIMIENTOS}

Muchos de los resultados presentados en este trabajo han sido posibles gracias a la ayuda, motivación y coraje de la Dra. M. Ángeles Vicente . Hernández. quien falleció en abril de 20()). Éste es un homenaje a su memoria, que nos acompañará siempre. El trabajo ha sido subvencionado por: a) Proyecto "IEDER" 1FD97-(0417. b) Proyecto "CICYT"' MAT2()(0)-(0972-C(02-()1. c) Proyecto "CS" $12 / 98$ y d) una beca de formación de la Junta de Castilla y I cón (190)6-99).
The change undergone by the Red variety are reflected in another four larieties of stone (Brown, Stripes. Nodular and White), clearly defined with respect to one another both as regards their aspect and texture and their degree of compactness and hardness, rendering them very much appreciated for use in construction. This is why since remote times the inhabitants of Ciudad Rodrigo have used the most transformed rarieties (Striped Nodular and fine White) owing to the advantageous properties that the diagenetic transformations have afforded the original stone.

\section{AKNOWLEDGEMENTS}

Many of the results presented in this work have been possible thanks to the help, motivation and courage of Ir: M. A. Vicente Hernánde-. who died in april 2000. This is homage to her memory: The rork has been supported by: (a) Project "FEI)ER" (FI)97-(04/7, b) Projed "CICYT" MAT200()-()972-(02-01, c) Project "CS" 12198 and d) a grant of formation 11996-99) of the Junta de' Castilla y Léoin. 


\section{BIBLIOGRAFÍA}

(1) Martín, D.: Albert, V. López, M.: Rodríguez. M. D. Mapa geológico de España 1:50.00). Hoja 525. Ciudad Rodrigo. I.T.G.E. Madrid. 199() .

(2) Bascones. L: Rodriguez. M. D. Mapa geológico de España 1:50.000. Hoja 526. Serradilla del Arroyo. I.T.G.E. Madrid. 1991.

(3) Molina, E.: Cantano, M.: Vicente. M. A.: García. P. Some aspects of Paleoweathering in the Iberian Hercynian massif. Catena, 13. (1990). pp. $3333-346$.

(4) Jorda. J. F. Evolución morfotectónica de la vertiente noroeste de la Sierra de Francia y su relación con la Fosa de Ciudad Rodrigo. Salamanca. Revista provincial de estudios. 8. (1983). pp. 129-168.

(5) Alonso, G.: Cantano. M. La Formación Areniscas de Ciudad Rodrigo: ejemplo de sedimentación controlada por paleorrelieves (Eoceno. Fosa de Ciudad Rodrigo). Stvd. Geol. Salmant. Univ. Salamanca. 24. (1987). pp. 247-258.

(6) Cantano, M.: Molina. E. Aproximación a la evolución morfológica de la Fosa de Ciudad Rodrigo. Salamanca. Bol. R. Soc. Esp. Hist. Nat. (Geol.). 82(1-4). (1987).pp. 87-101.

(7) Cantano. M. Evolución morfodinámica del sector suroccidental de la cuenca de Ciudad Rodrigo. Salananca. Tesis Doctoral. Univ. de Huelva. Inédita. p. 277. Huelva. 1996

(8) Sendin. M. Arquitectura y Heráldica de Ciudad Rodrigo) (s. XV-XVI). Centro Estudios Salmantinos - C.S.I.C. p. 153. Salamanca. 1972.

(9) Varas. M. J. Estudio de los materiales pétreos más empléados en la construcción y sucesiras restauraciones de los édificios de interés histórico de Cïudad Rodrigo, Salamanca. Tesis Doctoral. Dpto. de Geología. Fac. de Ciencias. Univ. de Salamanca. Inédita. p. 322. Salamanca. 200).

(10) Lucas, G.: Cros. P.: Lang. J. Les roches sédimentaires. 2. Étude microscopique des roches méubles et consolidées. Doin. Ed. p. 503. Paris. 1976.

(11) Nahon. D. Introduction to the petrology of soils and chemical weathering. Wiley. Ed. p. 313. New York. 1991.

(12) Delvigne. J. E. Atlas of Micromorphopogy of mineral alteration and weathering. The Canadian Mineralogist. Special Publ. 3. ORSTOM. Ed. p. 494. 1998.

(13) Molina. E. Las paleoalteraciones en el zicalo Hercínico Ibérico: Fundamentos metodológicos y perfiles tipo. En. La evolución del relieve en zócalos antiguos: Procesos, formaciones superficiales y sedimentos asociados. Stvdia Geol. Salmanticensia. Vol. Esp. 7. (1998). pp. 87-100. Salamanca.

(14) Boulet. R.: Bocquier. G.: Millot, G. Géochimie de la surface ê formes du relef. I. Déséquilibre pédoclimatique dans les counertures pédologiques de l'Afrique tropical de l'Ouest et son rôle dans l'aplanisement dés reliefs. Sci. Geol. Bull., 30. (1977). pp. 235-243. Strasbourg.

(15) Thiry. M. Sédimentation continentales ét altérations associés: calcitisations, ferruginisations et silicifications. Les argiles plastiques du Sparnacien du Bassin de Paris. Sci. Geol. Mem.. 46. (1981). p. 173. Strasbourg.

(16) Bullock, P.; Fedoroff, N.; Jongerius, A. Stoops, G.; Tursina. T.; Babel, U. Handbook for Soil Thin Section Description. Wain Research Publications. p. 152. London. 1985

(17) JCPDS. Mineral powder diffication file. Minerals. International Centre for Diffraction Data. U.S.A. 1986

(18) Brindley, G.W.; Brown, G., Eds. Crystal structures of clay minerals and their X-ray identification. Mineralogical Society London. 1980.

(19) Lindholm. R. Mineral identification using X-ray diffraction. In: A practical approach to Sedimentology. Allen \& Unwin London. 1987.

(20) Hardy, R.; Tucker, M. X-ray powder diffraction of sediments. In: Techniques in Sedimentology. M. Tucker, Ed. Blackwel Scientific Publications. (1989). pp. 191-228.

(21) Schultz. L.G. Quantitative interpretation of mineralogical composition from X-ray and chemical data for the Pierre Shale. Geol. Survey. Prof. Paper. Vol. 391-C. 1964.

(22) Davies, T. T.; Hopper, P.R. Determination of the calcite: aragonite ratio in mollusc shells by X-ray diffraction. Miner Mag., 33. (1963).pp. 608-612.

(23) Runnells. D.D. Errors in X-ray of carbonates due to solid-solutions variation in composition of component minerals Jour. Sed. Petrol., 40. (1970). pp. 1158-1166.

(24) Barahona, E. Arcillas de ladrillería de la provincia de Granada. Evolución de algunos ensayos de materias primas. Tesi: Doctoral. Univ. Granada. Serv. Publ. N”49. p. 398. Granada. 1974.

(25) Mackenzic. R. C., Ed. Differential Thermal Analysis. Fundamental aspects. Vol. 1. Academic Press. p. 775. London anc New York. 1970),

(26) Paterson, E.; Swaffield, R. Thermal analysis. In: A handbook of determinative methods in clay mineralogy. M.J. Wilson

Ed. Blackie. Chapman and Hall. (1987). pp. 99-133. New York.

(27) Munsell. Munsell Soil Color Charts. Munsell Products. Baltimore. Maryland. 21218. 1976.

(28) CIE (Commission International de l'Eclaraige). Recommendations on uniform color spaces, color difference equations psychometric color terms. Supplement n" 2 to CIE publication n"15. Colorimetry. Bureau Central de la CIE. Paris. 1976.

(29) RII.EM I-2. Bulk densities and real densities. Paris. 1980.

(30) RII.EM II-2. Coefficient de conductivité de lapeur d'eaur. Paris. 1978.

(31) NORMAL. 7. Assorbimento d'acqua per inmersione totale.. Capasitá di Imbibizione. CNR-ICR. Roma. 1981.

(32) NORMAL 11. Assorbimente d'acqua per capillaritá. Coefficiente di Assorbimento Capillare. CNR-ICR. Roma. 1985

(33) NF, B10-503. Mesures de la porosité de la masse volumique réelle ét de la masse volumique apparente. Paris. 1973. 